\title{
Mikrokozmos zadružnog gospodarstva: gdje i kako posluju hrvatske zadruge?
}

\author{
Tanja Broz
}

Ekonomski institut, Zagreb, Hrvatska

e-mail: tbroz@eizg.hr

\section{Sandra švaljek}

Hrvatska narodna banka, Zagreb, Hrvatska

e-mail:ssvaljek@hnb.hr

\begin{abstract}
SAŽETAK Cilj je ovog rada analizirati zadružno gospodarstvo u Hrvatskoj kako bi se utvrdilo u kojoj je mjeri ono prisutno, kako posluje te ukazati na probleme koji bi aktivnijim bavljenjem tim područjem mogli biti ublaženi. Analiza je pokazala da je taj segment gospodarstva u Hrvatskoj razvijen daleko manje nego što bi to objektivno bilo moguće. Zadruge obuhvaćaju vrlo malen dio hrvatskog gospodarstva te uz to u prosjeku imaju slabije poslovne pokazatelje od ostatka gospodarstva. Međutim, budući da zadruge mogu povećati učinkovitost poslovanja članova zadruge, postoji velik neiskorišteni gospodarski potencijal, koji se sastoji od mogućnosti udruživanja pojedinih poduzetnika u zadruge.
\end{abstract}

Ključne riječi: zadruge, zadružno gospodarstvo, regionalna rasprostranjenost, financijski pokazatelji.

\section{Uvod}

Pojam zadrugarstva nije nov niti je svojstven samo Hrvatskoj. Udruživanje u zadruge poznato je još iz 18. stoljeća, kada su osnovane prve potrošačke zadruge, dok su prve moderne zadruge osnovane u Njemačkoj i Engleskoj sredinom 19. stoljeća. Zadružno gospodarstvo zatim se proširilo u druge dijelove svijeta, te je još 1895 . osnovan Međunarodni savez zadruga (engl. International Co-operative Alliance), koji je zaslužan za daljnji rast interesa za zadružno poduzetništvo. Zadruge su rasprostranjene svuda u svijetu jer pružaju idealan oblik organiziranja onima koji u poslovanju žele zadržati neovisnost kao fizičke ili pravne osobe, a istodobno iskoristiti prednosti okrupnjavanja. Okupljanje u zadrugu fizičkim osobama te malim i srednjim poduzetnicima omogućuje podjelu rizika, ulaganja u strojeve i opremu koji bi im inače bili nedostupni, lakši pristup tržištu, bolju pregovaračku poziciju 
kod nabave i plasmana proizvoda te povećava njihov kapacitet za razvoj menadžmenta, usavršavanje i istraživanje. Danas zadruge zauzimaju značajan udio u granama u kojima djeluju jaka trgovačka društva, kao što su bankarstvo, osiguranje i poljoprivreda. Osim toga, pokazalo se da su zadruge prikladan model poslovanja u brzorastućim granama kao što su zdravstvene usluge, obrazovanje, iskorištavanje obnovljivih izvora energije, poslovne usluge i stanovanje. U novije vrijeme, s pojavom ekonomije suradnje, dodatno je ojačao interes za zadruge jer zadružni poslovni model dobro odgovara takvoj vrsti poslovanja.

Uz razvoj zadružnog poduzetništva u svijetu pojavljuju se i istraživanja koja se bave zadrugama, te je danas literatura o zadružnom gospodarstvu u svijetu vrlo opsežna. Istražuju se, između ostalog, financijske i operativne karakteristike zadruga te njihov utjecaj na ukupno gospodarstvo i dohodak kućanstava (Hoken i Su, 2018.).

Iako se u svijetu spoznala važnost zadružnog gospodarstva, Hrvatska zaostaje i po značaju zadružnog gospodarstva i po istraživanjima koja se bave zadružnim gospodarstvom. Razloge vjerojatno treba tražiti u tome što se sam pojam zadruga poistovjećuje s prošlim sustavom te se doživljava kao relikt prošlosti, a ne kao potencijalno uspješan model poslovnog udruživanja. Stoga ovo istraživanje ima za cilj analizirati sadašnje stanje zadružnog poduzetništva u Hrvatskoj kako bi se utvrdilo u kojoj je mjeri ono prisutno u Hrvatskoj, kako posluje te ukazati na probleme koji bi aktivnijim bavljenjem tim područjem mogli biti ublaženi.

U nastavku rada prikazane su karakteristike zadružnog poduzetništva u Hrvatskoj, zatim se analizira regionalna i sektorska zastupljenost zadruga te njihovi poslovni rezultati. Naposljetku slijedi diskusija i zaključci analize.

\section{Karakteristike zadružnog poduzetništva u Hrvatskoj}

Sukladno Zakonu o zadrugama (NN 34/2011), zadruga je dragovoljno, otvoreno, samostalno i neovisno društvo kojim upravljaju njezini članovi te ostvaruju, unapređuju i zaštićuju pojedinačne i zajedničke potrebe i interese (gospodarske, socijalne, obrazovne, kulturne i druge) i ostvaruju ciljeve zbog kojih je zadruga osnovana. Zadruga se temelji na zadružnim vrednotama - samopomoći, odgovornosti, demokratičnosti, ravnopravnosti, pravičnosti i solidarnosti te moralnim vrednotama poštenja, otvorenosti, društvene odgovornosti i skrbi za lokalnu zajednicu. Odnosi među članovima zadruge uređuju se na zadružnim načelima dragovoljnog i otvorenog članstva, nadzora poslovanja od strane članova, gospodarskog sudjelovanja članova zadruge i raspodjele dobiti (na razvitak zadruge, porast pričuva i na članove razmjerno poslovanju sa zadrugom), načelima samostalnosti i neovisnosti, obrazovanja, stručnog usavršavanja i informiranja članova zadruge, suradnje među zadrugama i brige za zajednicu.

Definicija zadruga iz postojećeg Zakona o zadrugama odgovara onoj Međunarodne organizacije rada (engl. International Labor Organization - ILO), sadržanoj u Preporuci o unapređenju zadruga (International Labor Organization, 2002.) te u Izjavi 
o zadružnom identitetu usvojenoj na Generalnoj skupštini Međunarodnog saveza zadruga održanoj 1995. godine u Manchesteru (International Co-operative Alliance, 1995.). U tim dokumentima međunarodnih organizacija zadruga se definira kao „samostalno udruženje osoba dobrovoljno udruženih radi ostvarivanja gospodarskih, socijalnih i kulturnih potreba i htijenja putem zajedničkog vlasništva i demokratskog upravljanja poduzećem“. Zakon o zadrugama usklađen je s navedenim ključnim međunarodnim dokumentima i u pogledu zadružnih vrednota i načela.

Iz zadružnih vrednota i načela može se uočiti da se zadruge razlikuju od drugih oblika gospodarskog djelovanja. U prvom redu to se očituje u ciljevima, koji su kod zadruge zadovoljenje potreba članova, a kod drugih vrsta poduzeća ostvarivanje profita (Soboh i sur., 2009.). Zadruge izravno surađuju sa svojim članovima, služe im te im raspodjeljuju zadružni višak prema volumenu ostvarenih transakcija, a ne prema uloženom kapitalu. Zbog takvih razlika u ciljevima dolazi i do razlike u poslovnim strategijama i obrascima ponašanja između zadruga i drugih poduzetnika, te posljedično do razlike u financijskoj uspješnosti (Gentzoglanis, 1997.). Tako na primjer zadruge u načelu imaju niži povrat na kapital. Međutim, članovi zadruge ostvaruju druge koristi, kao što su više cijene za proizvode koje predaju zadruzi, niže cijene inputa koje nabavljaju preko zadruge te zajednički nastup na tržištu. Osim razlike u povratu na kapital, zadruge se od ostalih poduzetnika razlikuju i po zaduženosti. Naime, zadruge su često zaduženije od drugih poduzetnika zbog toga što im kapital, uz zadržanu dobit, čine samo članarine zadrugara, pa se stoga moraju više oslanjati na zaduživanje (Gentzoglanis, 1997.).

S druge strane, zadruge se ne osnivaju samo zbog zadovoljenja potreba svojih članova. Naime, u tržišnim ekonomijama proizvođači ili potrošači osnivaju zadruge i zbog nezadovoljstva ponašanjem profitnih poduzeća (Nilsson, 2001.). Zbog toga se ponekad na zadruge gleda kao alat za ispravljanje tržišnih neuspjeha, odnosno putem zadruga se može izbjeći plaćanje neopravdano visokih cijena u koje je ugrađen ekstraprofit monopolističkih poduzeća (Lerman i Parliament, 1990.). Ipak, unatoč brojnim pozitivnim odrednicama, zadruge su i predmet kritika, i to prvenstveno zbog potencijalno neefikasnog procesa donošenja odluka i ograničenja u pribavljanju kapitala (Kalogeras i sur., 2013.), ali i zbog moguće lošije kvalitete proizvoda i reputacije (Pennerstorfer i Weiss, 2009.; Hanf i Schweickert, 2014.). Do problema u donošenju odluka može doći zbog različitih ciljeva između članova zadruge ${ }^{1}$, ali i između članova i upravitelja zadruge, što se posebno događa kada zadruga dosegne veći stupanj kompleksnosti u poslovanju (Svendsen, 2007.). Za razliku od problema u donošenju odluka, koji se može ublažiti kada strategija poslovanja dovodi do Pareto optimalne alokacije resursa (Svendsen, 2007.), problem s kapitalom zadruge mogu riješiti različitim oblicima dokapitalizacije (Kalogeras i sur., 2009.), što im u konačnici omogućuje smanjeno zaduživanje.

1 Do različitih ciljeva dolazi zbog maksimiziranja vlastitog profita svakog pojedinog člana zadruge (Fulton and Giannakas, 2001.). 
Iako literatura navodi mnoge koristi od osnivanja i poslovanja zadruga, one su, međutim, dio gospodarstva koji država često zanemaruje i koji najčešće nije predmet razrađenih javnih politika. U posttranzicijskim zemljama zadruge su osim toga i stigmatizirane (Gijselinckx i Bussels, 2014.), što predstavlja dodatnu prepreku suvremenom razvoju zadruga kao dijela njihovog gospodarskog sustava. Naime, u tim se zemljama pojam zadruge još uvijek neopravdano povezuje s ograničenjima u pogledu slobodnog raspolaganja zemljištem i tržišnog bavljenja poljoprivredom, koja je bila predmet centralnog planiranja. No, upravo suprotno, zadruge bi u tim zemljama bile idealan odgovor na stvarno stanje u pogledu zemljišta i obavljanja poljoprivredne djelatnosti. U svim tim zemljama poljoprivredno je zemljište tijekom tranzicije privatizirano tako da su nastali brojni mali i srednji posjedi i tvrtke za preradu. Takva fragmentirana struktura ne dopušta da se iskoriste prednosti ekonomije obujma, a mali poduzetnici nemaju dovoljno kapitala za ulaganja u nove tehnologije koje su potrebne kako bi poljoprivrednici dosegli visoke sanitarne i fitosanitarne standarde. Osnivanje zadruga stoga u tim zemljama predstavlja način da se postigne kritična veličina i poduzmu veća ulaganja u onom dijelu poljoprivrede koji čine mala obiteljska poljoprivredna gospodarstva.

U Hrvatskoj je od 90-ih godina prošlog stoljeća zadružno poduzetništvo također stigmatizirano kao način obavljanja djelatnosti svojstven socijalističkom društvenom uređenju, iako takva kvalifikacija nije točna (Matijašević, 2005.; Tratnik, Stracenski i Radinović, 2005.; Nedanov, Franić i Gugić, 2012.). Zadruge su se, naime, u Hrvatskoj pojavile puno prije nastanka socijalizma, a od 1960-ih godina zadruge, osobito one poljoprivredne, nisu uživale podršku tadašnjeg državnog vodstva (Mataga, 2005.). Stoga bi se moglo reći da je slika o zadrugama kao socijalističkom reliktu stvorena tijekom gospodarske transformacije zemlje, i to u interesu onih koji su se u nesređenim okolnostima tranzicije i poraća željeli domoći zadružne imovine. Zadružna imovina nije bila predmet pretvorbe i privatizacije, pa je mogla doći u ruke privatnih vlasnika samo nakon stečaja i likvidacije zadruga. Smišljeno stvaranje negativnog imidža zadruga poslužilo je lakšem dovođenju zadruga do ekonomske propasti u ionako nestabilnom gospodarskom okruženju. Imovina zadruga nakon likvidacije pripadala bi državi, a nakon toga je ta imovina često povoljno prodavana različitim interesnim skupinama (Nedanov i sur., 2012.).

Uzevši u obzir relativno slabu konvergenciju Hrvatske prema razvijenijim članicama EU-a, zaključuje se da je za gospodarski razvoj zemlje od važnosti svaki oblik gospodarskog djelovanja i gospodarska aktivnost u svim dijelovima zemlje. Hrvatska si stoga ne može dopustiti da zanemari zadružno poduzetništvo i da ne iskoristi prednosti tog poslovnog modela. 


\section{Regionalna i sektorska rasprostranjenost zadruga}

Ukupan broj zadruga u Hrvatskoj danas je relativno malen. Taj broj, doduše, raste, no ponajprije kao rezultat državne intervencije, odnosno potpora koje Ministarstvo hrvatskih branitelja daje za osnivanje braniteljskih zadruga. Prema podacima Financijske agencije, zadruga je u 2017. godini bilo 904, koliko ih je predalo financijska izvješća. ${ }^{2}$

Iako zadruge postoje u svim županijama, one nisu ravnomjerno raspoređene (tablica 1). Najviše ih je u Splitsko-dalmatinskoj (129) i Osječko-baranjskoj županiji (90) te u Gradu Zagrebu (84), odnosno upravo u onim županijama u kojima se nalazi najveći udio hrvatskih branitelja ${ }^{3}$. Najmanje se zadruga nalazi u Međimurskoj i Požeško-slavonskoj županiji (po 11), a to su županije, uz Ličko-senjsku županiju, u kojima se pak nalazi najmanji udio od ukupnog broja hrvatskih branitelja ${ }^{4}$. Osim što u Splitsko-dalmatinskoj županiji živi relativno velik udio hrvatskih branitelja koji se mogu prijaviti za korištenje potpora Ministarstva hrvatskih branitelja, u toj županiji djeluje Zadružni savez Dalmacije. Taj savez s tradicijom duljom od jednog stoljeća uspijeva pomagati postojećim i potencijalnim novim zadrugama, što je također doprinijelo tome da se u toj županiji danas nalazi najveći broj zadruga.

Međutim, budući da se županije razlikuju po broju stanovnika, tako je i zastupljenost zadruga po županijama drugačija ako u obzir uzmemo veličinu županije mjerenu brojem stanovnika. U tom slučaju najviše zadruga imaju Šibensko-kninska (4,7 na 10.000 stanovnika) i Bjelovarsko-bilogorska županija (4,6 na 10.000 stanovnika). Najmanje zadruga na 10.000 stanovnika imaju Primorsko-goranska županija, Grad Zagreb i Međimurska županija (po jednu zadrugu na 10.000 stanovnika).

2 Međutim, teško je točno utvrditi koliko zapravo postoji zadruga, budući da se broj zadruga u Hrvatskoj razlikuje s obzirom na korišteni izvor podataka. Izvor podataka koji se koristi u ovom istraživanju godišnja su financijska izvješća koje zadruge moraju dostavljati Financijskoj agenciji. Prema tom su izvoru u 2017. godini, koja je zadnja trenutno dostupna godina za analizu, u Hrvatskoj postojale ukupno 904 zadruge. S druge strane, prema Registru poslovnih subjekata, koji vodi Državni zavod za statistiku, broj aktivnih zadruga u istoj godini iznosio je 973. Valja napomenuti da navedeni registar ima upisane sveukupno 4482 zadruge, ali su tri četvrtine neaktivne. Također, u Evidenciji zadruga i zadružnih saveza, koju vodi Hrvatski centar za zadružno poduzetništvo, stoji da je u 2016. godini bilo evidentirano 1218 zadruga (Hrvatski centar za zadružno poduzetništvo, 2017.).

3 Prema podacima Državnog zavoda za statistiku i Ministarstva hrvatskih branitelja (Šućur, Babić i Ogresta, 2017.), od ukupnog broja branitelja, najveći dio branitelja živi u Gradu Zagrebu (14,7 posto) te u Splitsko-dalmatinskoj (10 posto) i Osječko-baranjskoj županiji (8,2 posto).

${ }^{4}$ U Međimurskoj županiji živi 1,7 posto svih branitelja, dok ih je u Požeško-slavonskoj 1,8 posto (Šućur i sur., 2017.). 


\begin{tabular}{|c|c|c|c|c|c|c|c|c|c|c|c|c|c|c|c|c|c|c|c|c|}
\hline 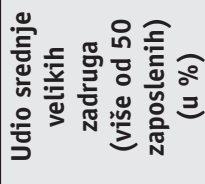 & 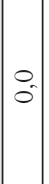 & $\because$ & : & $0^{\circ}$ & $\begin{array}{l}0 \\
0\end{array}$ & $\begin{array}{l}0 \\
0\end{array}$ & O & $\therefore$ & $\begin{array}{l}0 \\
0\end{array}$ & $\begin{array}{l}0 \\
0\end{array}$ & $:$ & in & & $\Rightarrow 0^{\circ}$ & 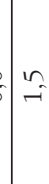 & $\begin{array}{l}0 \\
0\end{array}$ & $:$ & & $\Rightarrow$ & 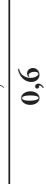 \\
\hline 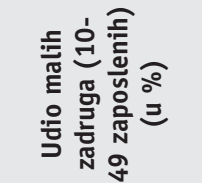 & 0 & ? & $\hat{v}$ & $0^{\circ}$ & $\begin{array}{c}0 \\
f\end{array}$ & $\begin{array}{l}10 \\
\forall f\end{array}$ & $\stackrel{\partial}{\Leftrightarrow}$ & 2 & in & $\left|\begin{array}{c}0 \\
\text { ri }\end{array}\right|$ & $\begin{array}{c}c \\
\infty \\
-1\end{array}$ & $\begin{array}{l}0 \\
0\end{array}$ & $\stackrel{n}{\rightarrow} \mid i$ & \begin{tabular}{lll}
$\mathcal{N}$ & $\mathcal{v}$ \\
\multirow{T}{*}{}
\end{tabular} & $=$ & $\mid \begin{array}{l}2 \\
6\end{array}$ & $\begin{array}{l}2 \\
\infty \\
\infty\end{array}$ & & 0 & $\stackrel{n}{4}$ \\
\hline 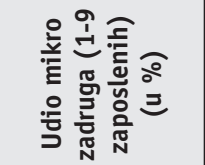 & $\vec{F}$ & $\frac{m}{m}$ & है & के & $\begin{array}{l}0 \\
\dot{b} \\
i\end{array}$ & $\mid \begin{array}{c}1 \\
\infty \\
0 \\
0\end{array}$ & $\begin{array}{l}\infty \\
8 \\
8\end{array}$ & ิิ & $\vec{F}$ & $\widehat{\jmath}$ & 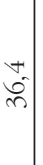 & $\overbrace{}^{2}$ & 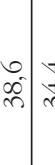 & $\begin{array}{l}+ \\
+ \\
t\end{array}$ & $\frac{n}{i n}$ & $\mid \begin{array}{l}2 \\
\stackrel{2}{+} \\
\stackrel{+}{*}\end{array}$ & $\begin{array}{l}0 \\
\text { in }\end{array}$ & & $\begin{array}{l}c \\
0 \\
0 \\
0\end{array}$ & \begin{tabular}{l}
$\infty$ \\
\multirow{f}{*}{}
\end{tabular} \\
\hline
\end{tabular}

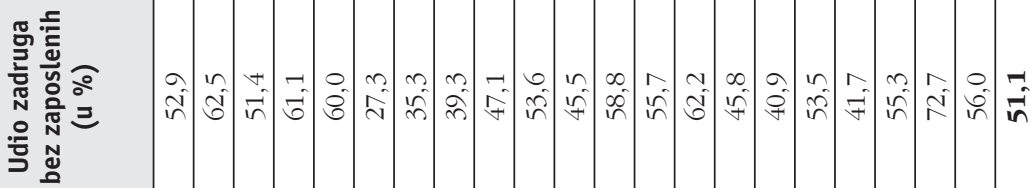

은 웅

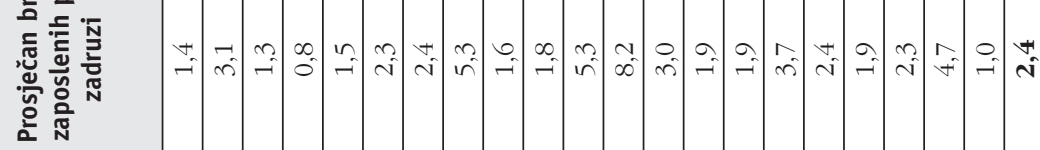

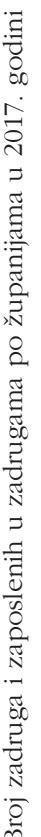

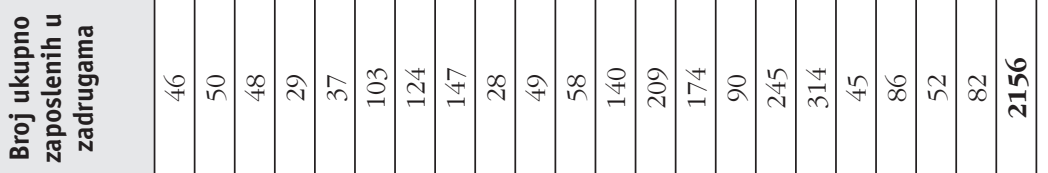

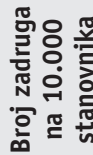

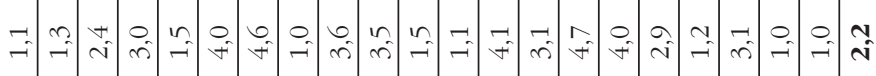

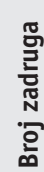

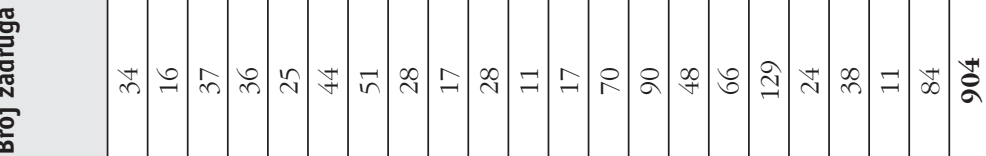

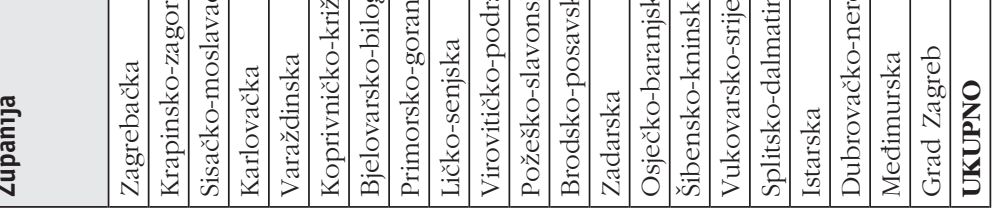

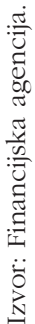


U svijetu, a tako i u Hrvatskoj, prema ukupnom broju najznačajnije su poljoprivredne zadruge. Poljoprivredne zadruge u ukupnom broju zadruga u Hrvatskoj sudjeluju s udjelom od 41,7 posto, dok su idući najzastupljeniji sektori prerađivačka industrija, u kojoj posluje 16,6 posto svih zadruga u Hrvatskoj, te sektor usluga, u kojem se nalazi 16,2 posto svih zadruga, dok se najmanji broj zadruga nalazi se u ribarstvu i turizmu (slika 1). Međutim, većina zadruga koje posluju u sektoru prerađivačke industrije zapravo se bavi preradom poljoprivrednih proizvoda, tako da udio zadruga koje se bave poljoprivredom i preradom poljoprivrednih proizvoda prelazi 50 posto. Takva visoka zastupljenost poljoprivrednih zadruga kao i njihova duga tradicija objašnjavaju zašto postoji percepcija javnosti da se zadruge odnose isključivo na poljoprivredu. S druge strane, poticanje razvoja poljoprivrednih zadruga od velikog je značaja budući da one pripomažu u sigurnoj opskrbi hranom i smanjuju siromaštvo te omogućuju ravnomjerniji regionalni i ruralni razvoj. Osim toga, povećavaju prihode poljoprivrednicima na način što im pomažu u zajedničkom nastupu na tržištu (International Co-operative Alliance, 2017.). Budući da je u Hrvatskoj u 2017. godini bilo gotovo 160 tisuća obiteljskih poljoprivrednih gospodarstava (Agencija za plaćanja u poljoprivredi, ribarstvu i ruralnom razvoju, 2018.), danas postoji velik neiskorišteni gospodarski potencijal u području poljoprivrede, a koji se sastoji od mogućnosti udruživanja vrlo velikog broja obiteljskih poljoprivrednih gospodarstava u zadruge. Upravo mogućnost okupljanja obiteljskih poljoprivrednih gospodarstava u zadruge kako bi ostvarili jednostavniji pristup tržištu može pomoći u njihovoj konkurentnosti te dati poljoprivrednom sektoru priliku za snažniji razvoj.

Iako su u većini županija zadruge u sektoru poljoprivrede najbrojnije, ipak postoje i neke županije u kojima su zadruge u drugim sektorima značajnije. Tako u Koprivničko-križevačkoj županiji najveći broj zadruga posluje u sektoru usluga i prerađivačkoj industriji, u Istarskoj županiji u sektoru usluga te u Gradu Zagrebu u sektoru usluga, prerađivačkoj industriji i građevinarstvu.

Slika 1.

Udio zadruga u ukupnom broju zadruga po sektorima, 2017. (u \%)

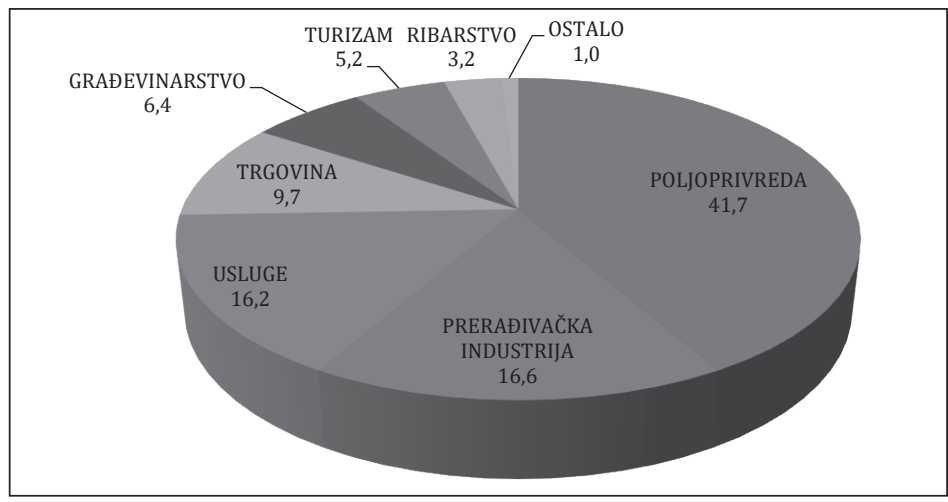

Izvor: Financijska agencija. 
U zadrugama je zaposlen relativno malen dio ukupno zaposlenih u Hrvatskoj. Zadruge zapošljavaju ukupno 2156 zaposlenika (tablica 1), što iznosi tek 0,2 posto ukupno zaposlenih u Hrvatskoj. Prosječan broj zaposlenih po zadruzi iznosi 2,4 zaposlenika, što je značajno manje od prosječnog broja zaposlenih po trgovačkom društvu u Hrvatskoj, koji iznosi 7,7. Samo je u Brodsko-posavskoj županiji, zahvaljujući jednoj srednje velikoj zadruzi, prosječan broj zaposlenih po zadruzi viši od prosječnog broja zaposlenih po trgovačkom društvu u Hrvatskoj $(8,2)$, dok je u ostalim županijama taj broj značajno niži od hrvatskog prosjeka. Međutim, valja imati na umu da zadruge često zadovoljavaju pojedine zajedničke potrebe članova pravnih osoba, koje pak glavninu aktivnosti obavljaju unutar svojih trgovačkih društava ili obrta te je stoga moguće očekivati da je u zadrugama zaposlen relativno malen broj ljudi.

Najznačajniji sektori za zadruge zapošljavaju i najveći broj radnika (tablica 2). Tako je u zadrugama u poljoprivrednom sektoru zaposleno 43,3 posto svih zaposlenika u zadrugama, dok ih je u prerađivačkoj industriji zaposleno dodatnih 18,8 posto. Najveća se zadruga također nalazi u sektoru poljoprivrede, ima 133 zaposlena, što čini 6,2 posto ukupnog broja svih zaposlenih u zadrugama, a sjedište joj je u Brodsko-posavskoj županiji.

Prosječan broj zaposlenih po zadruzi pokazuje da najviše zaposlenika ima sektor ribarstva, odnosno više od pet zaposlenika po jednoj zadruzi (tablica 2). Drugi sektori značajno zaostaju za ribarstvom.

Iako zadruge zapošljavaju prosječno 2,4 zaposlenika, većina zadruga ipak nema zaposlenog ni jednog zaposlenika (tablica 1). Tek pet zadruga ima više od 50 zaposlenika, što znači da spadaju u srednje velike poduzetnike, dok ne postoji ni jedna velika zadruga prema kriteriju broja zaposlenika, odnosno ni jedna nema više od 250 zaposlenika. Najviše zadruga bez zaposlenih nalazi se u Splitsko-dalmatinskoj i Osječko-baranjskoj županiji, ali to nije iznenađujuće budući da su to županije u kojima se nalazi i najveći broj zadruga. Međutim, ono što valja istaknuti je da u nekim županijama prevladavaju zadruge bez zaposlenih, kao npr. u Međimurskoj županiji, gdje 72,7 posto svih zadruga nema ni jednog zaposlenog te Krapinsko-zagorskoj, gdje 62,5 posto zadruga nema zaposlenih. Pet srednje velikih zadruga nije koncentrirano u jednoj županiji, već su raspršene po cijeloj Hrvatskoj - u Brodskoposavskoj, Osječko-baranjskoj, Vukovarsko-srijemskoj, Međimurskoj te Zadarskoj Županiji. 
Tablica 2.

Struktura zaposlenih u zadrugama, u 2017.

\begin{tabular}{|l|c|c|}
\hline Sektor & $\begin{array}{c}\text { Udio zaposlenih u ukupnom broju } \\
\text { zaposlenih u zadrugama (u \%) }\end{array}$ & Prosječan broj zaposlenih po zadruzi \\
\hline Poljoprivreda & 43,3 & 2,5 \\
\hline Ribarstvo & 7,1 & 5,3 \\
\hline Prerađivačka industrija & 18,8 & 2,7 \\
\hline Građevinarstvo & 3,2 & 1,2 \\
\hline Trgovina & 10,8 & 2,6 \\
\hline Turizam & 6,6 & 3,0 \\
\hline Usluge & 9,7 & 1,4 \\
\hline Ostalo & 0,5 & 1,1 \\
\hline UKUPNO & $\mathbf{1 0 0 , 0}$ & $\mathbf{2 , 4}$ \\
\hline
\end{tabular}

Izvor: Financijska agencija.

\section{Analiza poslovnih rezultata zadruga}

Uspjeh u poslovanju važan je pokazatelj napretka gospodarskog subjekta. Međutim, značajno je jednostavnije analizirati poslovanje poduzeća koje se bazira na transakcijama s tržištem od poslovanja zadruga, koje se uglavnom temelji na transakcijama s članovima društva te za koje ne postoje jednoznačno određene cijene (Gentzoglanis, 1997.). Naime, zadruge nisu kao druga profitna poduzeća, budući da u principu ne isplaćuju dobit članovima zadruge, nego se koristi ostvaruju kroz transakcije koje se obavljaju sa zadrugom. Njihov glavni cilj nije maksimizacija profita, nego zadovoljenje potreba članova, kao primjerice nabavka povoljnijih sirovina, pristup tržištu preko zadruge ili pristup proizvodima i uslugama koje im nisu drugdje dostupne (Chesnick, 2000.). Zbog toga je uspješnost poslovanja zadruga puno teže ocijeniti, što treba imati na umu kod analize poslovnih rezultata zadruga.

Iako se zadruge po ciljevima razlikuju od drugih poduzetnika, u analizi njihovog poslovanja koriste se uobičajeni pokazatelji poslovanja poduzeća. Tako se fokus stavlja na nekoliko važnih grupa pokazatelja - pokazatelje profitabilnosti, likvidnosti, zaduženosti i aktivnosti (Chesnick, 2000.). Međutim, budući da se pomoću tih pokazatelja uspješnosti poslovanja zadruge analiziraju kao da se radi o poduzetnicima usmjerenima prema ostvarivanju dobiti, to znači da se u obzir ne uzimaju dodatne koristi koje ostvaruju članovi zadruge (Lerman i Parliament, 1991.). Ipak, svi ti pokazatelji pomažu u tome da se uoče snage i slabosti poslovanja zadruga te da se usporedi poslovanje zadruga u različitim sektorima. Osim toga, na taj se način može empirijski provjeriti razlikuju li se zaista zadruge od ostalih oblika poduzetničkog djelovanja. U nastavku je stoga prikazana analiza financijskih pokazatelja primijenjenih na zadruge, i to za sve zadruge zajedno, po sektorima, veličini i poslovnom rezultatu te je napravljena usporedba s ostalim poduzetnicima u Hrvatskoj. 


\subsection{Analiza ukupnih poslovnih rezultata zadruga}

Iako registriranih zadruga prema Registru poslovnih subjekata koji vodi Državni zavod za statistiku ima više od četiri tisuće, njih tek 904 dostavilo je u 2017. godišnja financijska izvješća Financijskoj agenciji. Međutim, ni to ne znači da su sve 904 zadruge aktivne. Naime, 22 zadruge koje su dostavile izvješća u 2017. godini nisu imale nikakve prihode ni rashode (tablica 3). Dodatnih devet zadruga nije ostvarilo ni dobit ni gubitak, a među njima je većina imala zanemarivo nizak iznos prihoda i rashoda, što također ukazuje na njihovu slabu aktivnost. S dobiti su u 2017. poslovale 554 zadruge, dok je u gubitku bilo 319 zadruga.

Tablica 3.

Zadruge prema poslovnom rezultatu u 2017.

\begin{tabular}{|l|c|c|}
\hline & Broj zadruga & $\begin{array}{c}\text { Udio u ukupnom broju } \\
\text { zadruga (u \%) }\end{array}$ \\
\hline Broj zadruga s dobiti & 554 & 61,3 \\
\hline Broj zadruga s gubitkom & 319 & 35,3 \\
\hline $\begin{array}{l}\text { Broj zadruga s uravnoteženim poslovnim } \\
\text { rezultatom (bez dobiti ili gubitka) }\end{array}$ & 9 & 1,0 \\
\hline Broj zadruga bez prihoda i rashoda & 22 & 2,4 \\
\hline Ukupan broj zadruga prema FINA-i & $\mathbf{9 0 4}$ & $\mathbf{1 0 0 , 0}$ \\
\hline
\end{tabular}

Izvor: Financijska agencija.

Zadruge obuhvaćaju malen dio hrvatskog gospodarstva. Ukupan prihod zadruga u 2017. godini iznosio je 1,6 milijardi kuna (tablica 4), što je 0,3 posto ukupnih prihoda svih trgovačkih društava ${ }^{5}$, dok je prosječni godišnji prihod po zadruzi iznosio 1,8 milijuna kuna. Zadruge su u 2017. ostvarile ukupnu neto dobit u iznosu od 29,5 milijuna kuna, dok je njihova dobit prije oporezivanja te dobit prije oporezivanja, kamata i amortizacije iznosila 38,4, odnosno 123,4 milijuna kuna.

Kao što zadrugama nije cilj maksimizacija profita, tako ni povrat na kapital i imovinu zadruga ne treba gledati kao isključivu mjeru njihova uspjeha. Povrat na kapital stoga se može tumačiti kao potencijalni porast internog izvora kapitala (International Co-operative Alliance, 2017.). Iako zadruge imaju pozitivan povrat na kapital i imovinu, on je ipak značajno niži nego kod poduzeća u ostatku gospodarstva (tablica 5). To upućuje na slabiji potencijal povećanja internog izvora kapitala te potrebu oslanjanja na vanjske izvore za financiranje razvoja poslovanja. Kapitalna struktura zadruga pokazuje upravo to - tek se 32,8 posto poslovanja financira iz kapitala, dok ostatak otpada na obveze, a taj je udio financiranja iz kapitala ujedno i manji nego

5 Ukupan prihod svih trgovačkih društava odnosi se na ona društva koja su dostavila Financijskoj agenciji godišnja financijska izvješća. 
kod cjelokupnog hrvatskog gospodarstva. Ipak, takva struktura kapitala i obveza slična je drugim zadrugama u svijetu. ${ }^{6}$ Problem s kojim se općenito susreću zadruge je taj što teže dolaze do kapitala od ostalih poduzeća (International Co-operative Alliance, 2017.). Naime, inicijalni izvor financiranja za zadrugu uplate su članova zadruge. Međutim, član zadruge može izaći iz zadruge, a time i povući svoj članski ulog. To znači da kapital zadruge nije trajan, nego je podložan nestabilnosti, što otežava razvoj poslovanja zadruge. ${ }^{7}$ Osim toga, budući da zadruge imaju očekivano niži povrat na kapital te članovima s većim članskim ulogom u pravilu ne daju veća vlasnička prava, one su manje zanimljive ulagačima (Chieh i Weber, 2016.). Uz to, Hrvatska nije iznimka u odnosu države prema zadrugama. Problem u dolasku do kapitala za zadruge je taj što države često ne razumiju dovoljno potencijal zadruga da pokrenu razvoj gospodarstva (International Co-operative Alliance, 2017.) te ne smanjuju zapreke koje otežavaju poslovanje tom segmentu gospodarstva.

Tablica 4.

Odabrane stavke iz bilance i računa dobiti i gubitka zadruga i ukupnog gospodarstva u 2017., u mil. kuna

\begin{tabular}{|l|c|c|}
\hline & Zadruge ukupno & $\begin{array}{r}\text { Gospodarstvo } \\
\text { (bez zadruga) }\end{array}$ \\
\hline Ukupni prihod & $1.644,2$ & $663.987,8$ \\
\hline Prosječni prihod & 1,8 & 5,5 \\
\hline Ukupna neto dobit & 29,5 & $21.790,8$ \\
\hline Dobit prije oporezivanja & 38,4 & $28.534,3$ \\
\hline Dobit prije oporezivanja, kamata i amortizacije & 123,4 & $75.455,0$ \\
\hline Ukupna imovina (aktiva) & $2.302,4$ & $1.081 .256,8$ \\
\hline Ukupne obveze & $1.547,5$ & $650.016,9$ \\
\hline Prosječne obveze & 1,7 & 5,4 \\
\hline Kapital & 754,9 & $431.239,9$ \\
\hline
\end{tabular}

Izvor: Financijska agencija.

6 Treba napomenuti da se ovdje radi o usporedbi s najvećim zadrugama po prihodu. Kada usporedimo samo hrvatske zadruge koje ostvaruju dobit s najboljim svjetskim zadrugama, tada se uočava da hrvatske zadruge imaju veći udio kapitala u bilanci od inozemnih zadruga.

${ }^{7}$ Taj je problem posebno izražen kod štedno-kreditnih zadruga. 
Tablica 5.

Financijski pokazatelji zadruga i ukupnog gospodarstva u 2017.

\begin{tabular}{|c|c|c|}
\hline & Zadruge ukupno & $\begin{array}{r}\text { Gospodarstvo } \\
\text { (bez zadruga) }\end{array}$ \\
\hline \multicolumn{3}{|l|}{ Pokazatelji profitabilnosti } \\
\hline Povrat na kapital - ROE (u \%) & 3,9 & 5,1 \\
\hline Povrat na imovinu - ROA (u \%) & 1,3 & 2,0 \\
\hline \multicolumn{3}{|l|}{ Pokazatelji likvidnosti } \\
\hline Koeficijent tekuće likvidnosti & 1,0 & 1,1 \\
\hline Koeficijent ubrzane likvidnosti (u \%) & 0,7 & 0,8 \\
\hline Koeficijent trenutne likvidnosti (u \%) & 0,1 & 0,2 \\
\hline Koeficijent financijske stabilnosti (u \%) & 94,0 & 98,2 \\
\hline \multicolumn{3}{|l|}{ Pokazatelji zaduženosti } \\
\hline Koeficijent financiranja & 2,0 & 1,4 \\
\hline Koeficijent zaduženosti & 0,7 & 0,6 \\
\hline Pokriće troškova kamata (u \%) & 276,5 & 334,7 \\
\hline \multicolumn{3}{|l|}{ Pokazatelji aktivnosti } \\
\hline Obrtaj zaliha (u danima) & 157,0 & 149,1 \\
\hline Naplata potraživanja (u danima) & 70,7 & 55,9 \\
\hline Prosječno plaćanje obveza dobavljačima (u danima) & 188,5 & 153,7 \\
\hline \multicolumn{3}{|l|}{ Kapitalna struktura i struktura imovine } \\
\hline Kapitalna struktura - obveze (u \%) & 67,2 & 60,1 \\
\hline Kapitalna struktura - kapital (u \%) & 32,8 & 39,9 \\
\hline Udio dugotrajne imovine u aktivi (u \%) & 52,4 & 66,3 \\
\hline
\end{tabular}

Izvor: Financijska agencija.

Zbog specifičnosti u pribavljanju kapitala zadruge su zaduženije od ostatka gospodarstva. Budući da se većinom oslanjaju na kreditore, a ne na vlastita sredstva, koeficijent financiranja (omjer ukupnog duga i kapitala) im iznosi dva, što je značajno više nego u ostatku gospodarstva. Osim toga, imaju nepovoljniji koeficijent zaduženosti (omjer obveza i imovine) od ostatka gospodarstva. To upućuje na relativno slabiju kreditnu sposobnost i veći financijski rizik zadruga. Drugim riječima, to znači da u slučaju poslovnih poteškoća neke zadruge neće biti u mogućnosti izvršiti sve ugovorne obveze.

Osim što su relativno zadužene, zadruge nemaju ni usklađenu ročnu strukturu imovine i izvora financiranja (tablica 5). Naime, financijsku stabilnost zadruge pospješila bi uravnotežena struktura financiranja imovine. To znači da bi dugoročnu imovinu trebalo financirati iz dugoročnih izvora - kapitala i dugoročnih obveza. Međutim, zadruge dio dugotrajne imovine, iako ne prevelik dio, financiraju iz kratkoročnih izvora financiranja. To znači da je tijekom vremena korištenja imovine potrebno obnavljati kratkoročne obveze, što u slučaju likvidnosnih problema može biti otežano.

Pokazatelji likvidnosti pokazuju da bi zadruge mogle imati problema s održavanjem likvidnosti. Podaci u tablici 5 pokazuju da zadruge jedva pokrivaju kratkoročne 
obveze iz ukupne kratkotrajne imovine, što se ogleda u tome da im je koeficijent tekuće likvidnosti jednak jedan. To znači da bi u slučaju potrebe podmirivanja svih kratkoročnih obveza zadruge morale unovčiti cjelokupnu kratkotrajnu imovinu, uključujući i zalihe koje može biti problematično unovčiti u roku u kojem je potrebno podmiriti obveze. Međutim, čini se da velik dio kratkotrajne imovine zadruga čine upravo zalihe, budući da koeficijent ubrzane likvidnosti iznosi tek 0,7, odnosno zadruge u prosjeku lakše utrživom kratkotrajnom imovinom mogu pokriti tek 70 posto obveza.

Zadrugama je potrebno više od pola godine da zalihe pretvore u novac potreban za daljnje poslovanje. Naime, pokazatelj koji mjeri koliko efikasno zadruga prodaje zalihe, odnosno koliko dugo u prosjeku zalihe stoje u zadruzi, pokazuje da zadrugama u prosjeku treba 157 dana kako bi prodale zalihe, što je više nego u ostatku gospodarstva. Međutim, naplata često ne slijedi odmah nakon ispostavljanja računa, te zadruge naplaćuju svoja potraživanja u prosjeku za 71 dan.

\subsection{Analiza poslovnih rezultata zadruga po sektorima}

Analiza poslovnih rezultata zadruga po sektorima može pridonijeti donošenju odluka o usmjeravanju državnih potpora u razvoj zadruga. Osim toga, analiza po sektorima može otkriti u kojim sektorima zadruge bolje funkcioniraju - u tradicionalnim kao što je poljoprivreda ili onim usredotočenim na stvaranje veće dodane vrijednosti kao što je prerađivačka industrija. Stoga ce se ovo poglavlje usredotočiti na analizu poslovanja zadruga u različitim sektorima.

Poljoprivredne su zadruge najbrojnije, ali imaju nepovoljnije financijske pokazatelje od ostalih poduzetnika u poljoprivredi. Poljoprivrednih zadruga u Hrvatskoj ima 41,7 posto, a za zadružno su poduzetništvo još značajnije ako se promotre financijski pokazatelji. Poljoprivredne zadruge ostvaruju 51,9 posto svih prihoda zadruga te upravljaju s 50,3 posto imovine zadruga. S druge strane, u dugoročnim obvezama sudjeluju samo s 37,1 posto. Poljoprivredne su zadruge u 2017. godini ostvarile neto dobit (tablica 6), međutim prosječna neto dobit po zadruzi značajno je niža u poljoprivrednim zadrugama nego u ostatku poljoprivrednog sektora te su im također i povrati na kapital i imovinu niži od ostalih poduzetnika u poljoprivredi (tablica 7). Niži povrati na kapital i imovinu ne bi trebali nužno upućivati na probleme u poslovanju, međutim i drugi financijski pokazatelji pokazuju da su poljoprivredne zadruge općenito u lošijoj financijskoj poziciji od ostatka poljoprivrednog sektora. Poljoprivredne su zadruge zaduženije, što se očituje u tome što im je omjer ukupnog duga i kapitala, kao i omjer ukupnog duga i imovine, viši nego u prosjeku u ostatku poljoprivrednog sektora. Također, mogućnost pokrića troškova kamata iz dobiti prije oporezivanja i kamata značajno je niža kod poljoprivrednih zadruga nego kod ostalih poduzetnika u poljoprivredi. Osim toga, likvidnost poljoprivrednih zadruga niža je od ostatka poljoprivrednog sektora te im je duže vrijeme potrebno za naplatu potraživanja. S druge strane, značajno brže plaćaju svoje obveze prema dobavljačima, koji su zapravo često članovi zadruge, te imaju brži obrtaj zaliha. Unatoč relativno nepovoljnim pokazateljima, istraživanja pokazuju da i u drugim 
zemljama poljoprivredne zadruge imaju nižu profitabilnost i veću zaduženost te nižu efikasnost od drugih poduzetnika u poljoprivredi (Notta i Vlachvei, 2007.; Chaddad i Heckele, 2003.; Soboh, Lansink i Van Dijk, 2012.; Martínez-Victoria, Arcas Lario i Sánchez Val, 2018.).

Tablica 6.

Odabrane stavke iz bilance i računa dobiti i gubitka po sektorima u 2017., u mil. kuna

\begin{tabular}{|c|c|c|c|c|c|c|c|c|c|}
\hline & \multicolumn{2}{|c|}{ Poljoprivreda } & \multicolumn{2}{|c|}{ Ribarstvo } & \multirow[b]{2}{*}{ 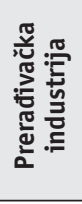 } & \multirow[b]{2}{*}{ 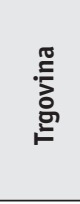 } & \multirow[b]{2}{*}{$\frac{\text { ज̆ }}{\Xi}$} & \multirow{2}{*}{ 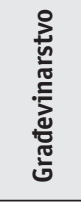 } & \multirow[b]{2}{*}{$\begin{array}{l}\text { E } \\
\text { N } \\
\text { E } \\
\text { E }\end{array}$} \\
\hline & $\begin{array}{l}\text { ğ } \\
\text { 롬 } \\
\text { N }\end{array}$ & 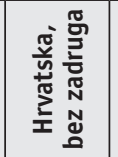 & 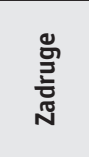 & 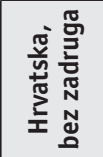 & & & & & \\
\hline Ukupni prihod & 853,7 & $16.218,5$ & 227,9 & $1.571,9$ & 225,3 & 144,0 & 112,9 & 51,7 & 27,6 \\
\hline Prosječni prihod & 2,3 & 5,8 & 7,9 & 5,4 & 1,5 & 1,6 & 0,8 & 0,9 & 0,6 \\
\hline Ukupna neto dobit & 5,0 & 466,8 & 3,3 & 85,9 & 6,7 & 0,6 & 11,1 & 1,2 & 2,1 \\
\hline Dobit prije oporezivanja & 8,8 & 608,4 & 4,1 & 103,1 & 8,4 & 0,9 & 12,4 & 1,5 & 2,7 \\
\hline Ukupna imovina (aktiva) & $1.158,7$ & $24.558,4$ & 140,8 & $3.205,4$ & 419,7 & 184,4 & 235,8 & 120,1 & 40,7 \\
\hline Ukupne obveze & 726,0 & $14.305,2$ & 93,7 & $2.329,2$ & 260,7 & 88,0 & 241,0 & 107,3 & 27,0 \\
\hline Prosječne obveze & 1,9 & 5,1 & 3,2 & 8,0 & 1,7 & 1,0 & 1,7 & 1,8 & 0,6 \\
\hline Kapital & 432,7 & $10.253,2$ & 47,1 & 876,2 & 159,0 & 96,4 & $-5,2$ & 12,8 & 13,7 \\
\hline
\end{tabular}

Izvor: Financijska agencija.

Tablica 7.

Financijski pokazatelji po sektorima u 2017.

\begin{tabular}{|c|c|c|c|c|c|c|c|c|c|}
\hline & \multicolumn{2}{|c|}{ Poljoprivreda } & \multicolumn{2}{|c|}{ Ribarstvo } & \multirow[b]{2}{*}{ 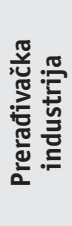 } & \multirow[b]{2}{*}{$\begin{array}{l}\stackrel{0}{5} \\
\text { 혼 }\end{array}$} & \multirow[b]{2}{*}{ 气ั } & \multirow[b]{2}{*}{ 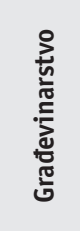 } & \multirow[b]{2}{*}{ 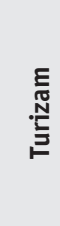 } \\
\hline & $\begin{array}{l}\text { ত্்̃ } \\
\text { 뮤 }\end{array}$ & 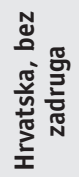 & 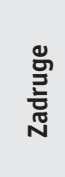 & 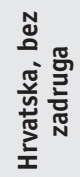 & & & & & \\
\hline \multicolumn{10}{|c|}{ Pokazatelji profitabilnosti } \\
\hline $\begin{array}{l}\text { Povrat na kapital - } \\
\text { ROE (u \%) }\end{array}$ & 1,2 & 4,6 & 6,9 & 9,8 & 4,2 & 0,6 & $* *$ & 9,2 & 15,5 \\
\hline $\begin{array}{l}\text { Povrat na imovinu - } \\
\text { ROA (u \%) }\end{array}$ & 0,4 & 1,9 & 2,3 & 2,7 & 1,6 & 0,3 & 4,7 & 1,0 & 5,2 \\
\hline \multicolumn{10}{|l|}{ Pokazatelji likvidnosti } \\
\hline $\begin{array}{l}\text { Koeficijent tekuće } \\
\text { likvidnosti }\end{array}$ & 0,9 & 1,2 & 1,4 & 1,1 & 1,3 & 0,9 & 1,0 & 1,2 & 0,8 \\
\hline $\begin{array}{l}\text { Koeficijent ubrzane } \\
\text { likvidnosti (u \%) }\end{array}$ & 0,6 & 0,8 & 1,1 & 0,4 & 0,6 & 0,6 & 0,8 & 1,1 & 0,7 \\
\hline $\begin{array}{l}\text { Koeficijent trenutne } \\
\text { likvidnosti (u \%) }\end{array}$ & 0,1 & 0,1 & 0,2 & 0,1 & 0,2 & 0,2 & 0,1 & 0,1 & 0,3 \\
\hline $\begin{array}{l}\text { Koeficijent financijske } \\
\text { stabilnosti (u \%) }\end{array}$ & 89,9 & 104,4 & 87,3 & 105,7 & 112,6 & 92,7 & $* *$ & 114,4 & 83,0 \\
\hline
\end{tabular}




\begin{tabular}{|c|c|c|c|c|c|c|c|c|c|}
\hline & \multicolumn{2}{|c|}{ Poljoprivreda } & \multicolumn{2}{|c|}{ Ribarstvo } & \multirow[b]{2}{*}{ 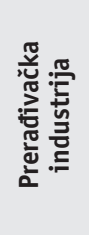 } & \multirow[b]{2}{*}{ 趈 } & \multirow[b]{2}{*}{$\stackrel{\text { ตั }}{\text { जั }}$} & \multirow[b]{2}{*}{ 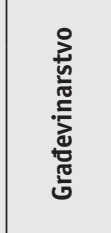 } & \multirow[b]{2}{*}{ 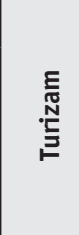 } \\
\hline & 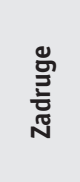 & 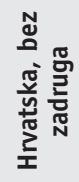 & 胥 & 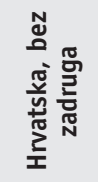 & & & & & \\
\hline \multicolumn{10}{|l|}{ Pokazatelji zaduženosti } \\
\hline Koeficijent financiranja & 1,7 & 1,3 & 2,0 & 2,5 & 1,6 & 0,9 & *** & 8,4 & 2,0 \\
\hline Koeficijent zaduženosti & 0,6 & 0,6 & 0,7 & 0,7 & 0,6 & 0,5 & 1,0 & 0,9 & 0,7 \\
\hline $\begin{array}{l}\text { Pokriće troškova } \\
\text { kamata (u \%) }\end{array}$ & 170,4 & 292,2 & 267,7 & 338,8 & 354,2 & 175,8 & 2001,1 & 215,9 & 1207,1 \\
\hline \multicolumn{10}{|l|}{ Pokazatelji aktivnosti } \\
\hline $\begin{array}{l}\text { Obrtaj zaliha (u } \\
\text { danima) }\end{array}$ & 144,6 & 247,8 & $29,3^{*}$ & $1445,7^{*}$ & 766,5 & 71,1 & $1529,7^{\text {*决 }}$ & $1093,1^{\text {***:* }}$ & 278,2 \\
\hline $\begin{array}{l}\text { Naplata potraživanja (u } \\
\text { danima) }\end{array}$ & 69,7 & 59,4 & 49,6 & 36,6 & 73,6 & 53,8 & 73,1 & 225,6 & 34,8 \\
\hline $\begin{array}{l}\text { Prosječno plaćanje } \\
\text { obveza dobavljačima } \\
\text { (u danima) }\end{array}$ & 161,3 & 205,9 & 67,4 & 213,6 & 437,6 & 181,8 & $2411,8^{* * * * *}$ & $5559,9^{* * * * *}$ & 329,6 \\
\hline \multicolumn{10}{|c|}{ Kapitalna struktura i struktura imovine } \\
\hline $\begin{array}{l}\text { Kapitalna struktura - } \\
\text { obveze (u \%) }\end{array}$ & 62,7 & 58,2 & 66,6 & 72,7 & 62,1 & 47,7 & *** & 89,3 & 66,3 \\
\hline $\begin{array}{l}\text { Kapitalna struktura - } \\
\text { kapital (u \%) }\end{array}$ & 37,3 & 41,8 & 33,4 & 27,3 & 37,9 & 52,3 & *** & 10,7 & 33,7 \\
\hline $\begin{array}{l}\text { Udio dugotrajne } \\
\text { imovine } \mathrm{u} \text { aktivi (u \%) }\end{array}$ & 55,1 & 61,5 & 56,7 & 49,1 & 61,4 & 64,8 & 18,2 & 35,6 & 60,8 \\
\hline
\end{tabular}

Napomena: *Važno je objasniti razliku u broju dana obrtaja zaliha između ribarskih zadruga i ostalih ribarskih poduzeća. Kod ribarskih zadruga taj je broj dana nizak jer članovi zadruge isporučuju zadruzi robu i naplaćuju je, što se evidentira kao trošak prodane robe, što povećava nazivnik u pokazatelju obrtaja zaliha. Kod ostalih ribarskih poduzeća, trošak je prodane robe nizak jer ribu koju prodaju sami love. Zbog toga je taj pokazatelj vrlo visok kod ostalih ribarskih poduzeća, a relativno nizak kod ribarskih zadruga. ** Ne može se izračunati jer je kapital negativan. *** Sektori građevinarstva i usluga zbog prirode posla imaju male troškove prodane robe, zbog čega su im pokazatelji obrtaja zaliha i plaćanja obveza dobavljačima nerealno visoki.

Izvor: Financijska agencija.

Sektor koji se ističe po dobrim poslovnim rezultatima zadruga je ribarstvo. Ribarstvo obuhvaća tek 3,2 posto ukupnog broja zadruga, ali su zadruge u tom sektoru ostvarile najviše prosječne prihode - 7,9 milijuna kuna (tablica 6). I u većini drugih pokazatelja sektor se ribarstva ističe među zadrugama. Povrat na kapital i imovinu je, uz sektor turizma, u zadrugama u sektoru ribarstva najviši, likvidnost im je povoljna, 
a naplata potraživanja i osobito plaćanje dobavljačima povoljnije nego kod ostalih sektora (tablica 7). Kada taj sektor usporedimo s ostalim ribarskim poduzetnicima, i tada dolazimo do zaključka da ribarske zadruge posluju relativno dobro. Pritom ne treba zabrinjavati niži povrat na kapital i imovinu ribarskih zadruga od ostalih ribarskih poduzetnika, zbog ranije navedenih razlika u ciljevima. Ribarske zadruge uspijevaju imati povoljniju likvidnost i zaduženost od ostalih ribarskih poduzetnika te ispunjavaju svoje obveze brže. S druge strane, ono po čemu zaostaju financijska su stabilnost poslovanja i broj dana naplate potraživanja ${ }^{8}$.

Potpore ribarskim zadrugama koje su postojale od 2010. do 2016. godine mogu se uzeti kao jedno od objašnjenja za njihove dobre poslovne rezultate. Naime, prije i neposredno nakon ulaska Hrvatske u Europsku uniju Ministarstvo poljoprivrede, ribarstva i ruralnog razvoja u sedam je uzastopnih godina, od 2010. do 2016., dodjeljivalo potpore ribarskim zadrugama. Potpora ribarskim zadrugama bila je jedna od mjera potpore ribarskom sektoru kojima je cilj bio ojačati ribarski sektor državnom bespovratnom pomoći za kapitalna ulaganja i druga unapređenja poslovanja, kako bi taj sektor spremnije dočekao ulazak u EU i kako bi mogao konkurirati ribarskom sektoru u dotadašnjim članicama Unije. Mjera potpore ribarskim zadrugama jedinstvena je mjera po tome što su njezini korisnici izrijekom bile zadruge, a ne neki drugi pravni oblik obavljanja djelatnosti.

Svake godine Ministarstvo je donosilo za iduću godinu Pravilnik o dodjeli potpore ribarskim zadrugama (od 2010. do 2013.), odnosno Pravilnik o dodjeli potpore udruženjima u ribarstvu (od 2014. do 2016.). Naziv pravilnika promijenjen je u kasnijim godinama jer je obuhvat korisnika mjera proširen, te su osim ribarskih zadruga korisnici mjere postala i komorska udruženja, Hrvatska gospodarska komora i Hrvatska obrtnička komora. Pravilnikom se određivalo što će se točno podupirati, zatim novčani iznos potpore po korisniku za svaku mjeru i udio potpore u vrijednosti ulaganja. Konkretne mjere razlikovale su se od godine do godine, a obuhvaćale su potpore za kupnju zemljišta, zatim kupnju, izgradnju, dogradnju, adaptaciju i opremanje objekata, kupnju opreme, vozila-hladnjača i mehanizacije, plaće upravitelja ribarske zadruge i drugih administrativnih osoba, marketing i izradu poslovnog plana zadruge, osnivanje i početak rada zadruge, edukaciju članova ribarske zadruge i aktivnosti na ishođenju certifikata.

Najviši dopušteni iznos ukupne potpore ribarskim zadrugama varirao je od milijun kuna (2010. i 2013.) do 600 tisuća kuna (2015. i 2016.). U tablici 8 prikazani su podaci o broju dodijeljenih potpora za ribarske zadruge, ukupnom i prosječnom iznosu, za razdoblje od 2013. do 2016. godine.

$\mathbf{8}$ Treba napomenuti da, iako ribarske zadruge sporije naplaćuju potraživanja od ostalih poduzetnika u sektoru ribarstva, broj dana naplate potraživanja kod ribarskih zadruga niži je i od ostalih zadruga u prosjeku i od ostatka gospodarstva. 
Tablica 8.

Potpore za razvoj ribarskih zadruga i udruženja u ribarstvu od 2013. do 2016.

\begin{tabular}{|l|c|c|c|}
\hline & Broj dodijeljenih potpora & Ukupno isplaćene potpore & $\begin{array}{c}\text { Prosječni iznos potpore po } \\
\text { korisniku }\end{array}$ \\
\hline 2013. & 12 & 8.729 .982 & 727.499 \\
\hline 2014. & 14 & 7.102 .844 & 507.346 \\
\hline 2015. & 17 & 6.264 .154 & 368.480 \\
\hline 2016. & 19 & 4.149 .057 & 218.371 \\
\hline
\end{tabular}

Izvor: Ministarstvo poljoprivrede, Uprava ribarstva.

Prosječni dodijeljeni iznosi potpore za ribarske zadruge bili su razmjerno visoki, te su stoga mogli značajno utjecati na poboljšanje opremljenosti ribarskih zadruga, a time i na njihovu konkurentnost i financijske rezultate, te u konačnici opstanak na tržištu. Čini se da su navedene potpore ribarskim zadrugama zaista ispunile svoju svrhu, budući da i nakon prestanka dodjela potpora ribarske zadruge imaju povoljnije financijske rezultate od ostalih poduzetnika u sektoru ribarstva. Osim toga, na pozitivne učinke potpora zadrugama ukazuju i istraživanja o državnim potporama u drugim zemljama, koja pokazuju da potpore zadrugama u ključnim formativnim godinama imaju pozitivan utjecaj na njihov budući razvoj (Karami i Rezaei-Moghaddam, 2005.).

Zadruge u prerađivačkoj industriji ostvarile su, uz zadruge u sektoru usluga, najveću ukupnu neto dobit (tablica 6). Osim toga, ono po čemu se ističu zadruge u prerađivačkoj industriji relativno je niska zaduženost. Omjer ukupnog duga i kapitala je, uz trgovinu, u tom sektoru najniži, dok omjer dugoročnog financiranja i dugotrajne imovine pokazuje da je financijska stabilnost zadruga u tom sektoru vrlo dobra te da je prerađivačka industrija, uz sektor građevinarstva, jedini sektor koji ne mora financirati dugoročnu imovinu iz kratkoročnih izvora (tablica 7). S druge strane, obrtaj je zaliha spor (767 dana), a broj dana naplate potraživanja iznosi 2,5 mjeseca, što je više nego u prosjeku u zadrugama, ali i u ukupnom gospodarstvu. Također, u odnosu na prosjek zadruga i ukupnog gospodarstva prosječan broj dana plaćanja obveza dobavljačima iznimno je visok te iznosi 438 dana.

Sektor trgovine spada u srednje velike sektore prema ukupnom prihodu i imovini zadruga. Zadruge u tom sektoru u prosjeku ostvaruju 1,6 milijuna kuna prihoda te imaju milijun kuna obveza, što su, uz zadruge u sektoru turizma, najniže prosječne obveze. Ipak, ukupno gledajući, zadruge u tom sektoru imaju najniži povrat na kapital i imovinu, što se vrlo vjerojatno može pripisati velikoj konkurenciji u tom sektoru u Hrvatskoj. Zadruge u trgovini među najmanje su likvidnim zadrugama te imaju relativno slabu pokrivenost kamata s dobiti prije oporezivanja i kamata. Osim toga, zbog relativno niskog dugoročnog duga, omjer dugoročnih izvora financiranja i dugotrajne imovine ukazuje na to da se dio dugotrajne imovine financira iz kratkoročnih izvora. Budući da dugotrajna imovina ima udio u aktivi od 64,8 posto, što je najviše od svih sektora, vjerojatnost za probleme u financiranju dugotrajne imovine veća je nego kod drugih sektora. 
Zadruge u sektoru usluga u 2017. godini ostvarile su najveću neto dobit, u iznosu od 11,1 milijuna kuna. Na takav poslovni rezultat sektora najviše utjecaja imala je jedna štedno-kreditna zadruga u stečaju, i to zbog ostalih poslovnih prihoda ostvarenih u 2017. godini. Bez ostalih prihoda navedene štedno-kreditne zadruge sektor usluga ostvario bi gubitak. Usluge su jedini sektor koji ima negativan kapital, i to zbog prenesenih gubitaka štedno-kreditnih zadruga iz prethodnih godina. Budući da je kapital negativan, nije moguće izračunati kapitalnu strukturu zadruga u tom sektoru ni povrat na kapital i koeficijent financiranja. I zaduženost sektora usluga pod izrazitim je utjecajem štedno-kreditnih zadruga. Naime, koeficijent zaduženosti bez štedno-kreditnih zadruga pada s 1 na 0,7. Međutim, iako se koeficijent financiranja ne može izračunati zbog negativnog kapitala, kada izostavimo štedno-kreditne zadruge, taj je omjer i dalje relativno visok $(2,3)$, te se može reći da su zadruge u tom sektoru u prosjeku prezadužene.

Iako građevinarstvo po broju zadruga nije najmanji sektor, prema ukupnom prihodu i imovini, uz turizam, spada u najmanje značajne sektore. Zadruge u sektoru građevinarstva relativno su slične zadrugama u sektoru usluga, budući da u obama sektorima troškovi prodane robe čine relativno malen udio operativnih troškova. Sličnost između tih dvaju sektora vidljiva je i iz strukture aktive, gdje većina imovine spada u kratkotrajnu imovinu. Ipak, za razliku od sektora usluga, zadruge u građevinarstvu imaju pozitivan kapital, zbog čega je moguće analizirati kapitalnu strukturu zadruga te njihovu zaduženost. U sektoru građevinarstva kapitalna je struktura značajno okrenuta prema obvezama kao dominantnom izvoru financiranja, zbog čega je i koeficijent financiranja, koji pokazuje omjer ukupnog duga i kapitala, vrlo visok te iznosi 8,4 .

Zadruge u sektoru turizma imaju najmanji ukupni prihod od svih sektora, međutim ostvarile su višu neto dobit nego sektor trgovine i građevinarstva zajedno. Uz niske ukupne prihode zadruge u tom sektoru imaju i najniže prosječne prihode po zadruzi (0,6 milijuna kuna) te najniže prosječne obveze zadruga (0,6 milijuna kuna). Unatoč relativno niskim prosječnim obvezama, koeficijent financiranja, zbog kapitalne strukture u kojoj sa 66,3 posto prevladavaju obveze, upućuje na relativno visoku zaduženost zadruga u tom sektoru. Koeficijent tekuće likvidnosti pokazuje da su zadruge u tom sektoru najmanje likvidne, odnosno imaju najslabiju pokrivenost kratkoročnih obveza kratkotrajnom imovinom. Međutim, velik dio kratkoročne imovine u obliku je novca u blagajni i banci, što se očituje u najvišem koeficijentu trenutne likvidnosti od svih sektora. Zadruge u sektoru turizma uspijevaju najbrže od svih sektora naplatiti svoja potraživanja, dok s druge strane sporo plaćaju svojim dobavljačima.

\subsection{Analiza poslovnih rezultata zadruga prema broju zaposlenih}

Veličina zadruge može imati značajan utjecaj na njezine poslovne rezultate. Tako prosječni prihod po zadruzi pokazuje da, logično, veće zadruge ostvaruju i veći prosječni prihod. Međutim, ekonomija obujma postoji kada poduzetnici s većim brojem zaposlenih ostvaruju veći prihod po zaposlenom, što znači da su u takvom slučaju 
veći poduzetnici učinkovitiji u korištenju resursa u svrhu ostvarivanja prihoda. To se djelomično vidi i kod zadruga. Zadruge koje imaju od jednog do devet zaposlenih (mikrozadruge) ostvaruju 0,7 milijuna kuna prihoda po zaposlenom, a zadruge s više od 50 zaposlenih (srednje velike zadruge) ostvaruju 1,1 milijuna kuna prihoda po zaposlenom. ${ }^{9}$ Jedino zadruge koje imaju između 10 i 49 zaposlenih (male zadruge) ostvaruju nešto niži prihod po zaposlenom od mikrozadruga (tablica 9). U usporedbi s cijelim gospodarstvom, kod kojeg postoji kontinuirani porast prihoda po zaposlenom s porastom veličine poduzeća, pokazuje se da mikro i srednje velike zadruge ostvaruju veće prosječne prihode po zaposlenom od ostalih poduzeća u Hrvatskoj. Jedina kategorija u kojoj ostala poduzeća u Hrvatskoj ostvaruju veće prihode po zaposlenom od zadruga mala su poduzeća, a to je upravo ona kategorija zadruga koja odudara od obrasca prema kojem prihodi po zaposlenom monotono rastu s rastom poduzetnika.

Tablica 9.

Odabrane stavke iz bilance i računa dobiti i gubitka zadruga prema broju zaposlenih u 2017., u mil. kuna

\begin{tabular}{|l|c|c|c|c|}
\hline & Bez zaposlenih & $\begin{array}{c}\text { Mikro zadruge } \\
\text { (1-9 zaposlenih) }\end{array}$ & $\begin{array}{c}\text { Male zadruge } \\
\text { (10-49 } \\
\text { zaposlenih) }\end{array}$ & $\begin{array}{c}\text { Srednje velike } \\
\text { zadruge } \\
\text { (više od 50 } \\
\text { zaposlenih) }\end{array}$ \\
\hline Ukupni prihod & 71,0 & 715,1 & 450,6 & 407,5 \\
\hline Prosječni prihod & 0,2 & 1,8 & 11,0 & 81,5 \\
\hline $\begin{array}{l}\text { Prosječni prihod po } \\
\text { zaposlenom (zadruge) }\end{array}$ & - & 0,7 & 0,6 & 1,1 \\
\hline $\begin{array}{l}\text { Prosječni prihod po } \\
\text { zaposlenom (gospodarstvo) }\end{array}$ & - & 0,5 & 0,7 & 2,4 \\
\hline Ukupna neto dobit/gubitak & $-4,3$ & 13,1 & 18,3 & 4,1 \\
\hline Dobit prije oporezivanja & $-3,9$ & 17,2 & 21,0 & 291,7 \\
\hline Ukupna imovina (aktiva) & 460,4 & 901,3 & 649,0 & 175,1 \\
\hline Ukupne obveze & 524,5 & 516,0 & 331,9 & 35,0 \\
\hline Prosječne obveze & 1,1 & 1,3 & 8,1 & 317,1 \\
\hline Kapital & $-64,1$ & 385,3 & & 116,6 \\
\hline
\end{tabular}

Izvor: Financijska agencija.

9 Za zadruge bez zaposlenih nije moguće napraviti takvu vrstu analize. 
Tablica 10.

Financijski pokazatelji zadruga prema broju zaposlenih u 2017.

\begin{tabular}{|c|c|c|c|c|}
\hline & $\begin{array}{c}\text { Bez } \\
\text { zaposlenih }\end{array}$ & $\begin{array}{c}\text { Mikro } \\
\text { zadruge } \\
(1-9 \\
\text { zaposlenih) }\end{array}$ & $\begin{array}{c}\text { Male } \\
\text { zadruge } \\
(10-49 \\
\text { zaposlenih) }\end{array}$ & \begin{tabular}{|c} 
Srednje \\
velike \\
zadruge \\
(više od 50 \\
zaposlenih)
\end{tabular} \\
\hline \multicolumn{5}{|l|}{ Pokazatelji profitabilnosti } \\
\hline Povrat na kapital - ROE (u \%) & * & 3,4 & 5,8 & 2,0 \\
\hline Povrat na imovinu - ROA (u \%) & $-0,9$ & 1,4 & 2,8 & 0,8 \\
\hline \multicolumn{5}{|l|}{ Pokazatelji likvidnosti } \\
\hline Koeficijent tekuće likvidnosti & 0,6 & 1,2 & 1,2 & 1,4 \\
\hline Koeficijent ubrzane likvidnosti (u \%) & 0,6 & 0,9 & 0,6 & 0,7 \\
\hline Koeficijent trenutne likvidnosti (u \%) & 0,1 & 0,1 & 0,1 & 0,1 \\
\hline Koeficijent financijske stabilnosti (u \%) & $*$ & 101,0 & 107,5 & 131,4 \\
\hline \multicolumn{5}{|l|}{ Koeficijenti zaduženosti } \\
\hline Koeficijent financiranja & * & 1,3 & 1,0 & 1,5 \\
\hline Koeficijent zaduženosti & 1,1 & 0,6 & 0,5 & 0,6 \\
\hline Pokriće troškova kamata (u \%) & $-30,0$ & 364,9 & 427,5 & 169,9 \\
\hline \multicolumn{5}{|l|}{ Pokazatelji aktivnosti } \\
\hline Obrtaj zaliha (u danima) & 555,2 & 119,3 & 264,0 & 102,7 \\
\hline Naplata potraživanja (u danima) & 448,6 & 70,5 & 58,1 & 46,8 \\
\hline Prosječno plaćanje obveza dobavljačima (u danima) & $2.663,3$ & 173,6 & 161,6 & 78,6 \\
\hline \multicolumn{5}{|l|}{ Kapitalna struktura i struktura imovine } \\
\hline Kapitalna struktura - obveze (u \%) & $*$ & 57,3 & 51,1 & 60,0 \\
\hline Kapitalna struktura - kapital (u \%) & $*$ & 42,7 & 48,9 & 40,0 \\
\hline Udio dugotrajne imovine u aktivi (u \%) & 44,7 & 54,3 & 59,0 & 44,3 \\
\hline
\end{tabular}

Napomena: * Ne može se izračunati jer je kapital negativan.

Izvor: Financijska agencija.

Na mikrozadruge, koje su uz zadruge bez zaposlenih najbrojnije te koje zapošljavaju ukupno najveći broj radnika, otpada najveći dio ukupnih prihoda i imovine zadruga - 43,5, odnosno 39,1 posto (slike 2 i 3). Te su zadruge, kao i male i srednje velike zadruge, ostvarile neto dobit, dok su zadruge bez zaposlenih ostvarile gubitak.

O slaboj aktivnosti zadruga bez zaposlenih govori i to što su one ostvarile tek 4,3 posto ukupnih prihoda zadruga, a upravljaju s 20 posto ukupne imovine zadruga. 
Osim toga, značajan dio obveza otpada upravo na zadruge bez zaposlenih. One sudjeluju s 33,9 posto u ukupnim obvezama zadruga (slika 4), dok im kratkoročne obveze čine 35,6 posto svih kratkoročnih obveza zadruga. Zbog gubitaka u tekućoj godini, ali i prenesenih gubitaka iz prethodnih godina, kapital je u toj skupini zadruga negativan. Ipak i ostali pokazatelji ukazuju na otežano poslovanje zadruga bez zaposlenih. Likvidnost tih zadruga vrlo je niska, dok pokazatelji aktivnosti pokazuju iznimno neefikasno poslovanje (tablica 10). Stoga, ako zadruge imaju ozbiljnu namjeru razvijati svoj poslovni model i poslovanje, onda je preporučljivo da zaposle barem jednu osobu koja bi se u potpunosti posvetila poslovanju zadruge. To bi u konačnici trebalo poboljšati poslovanje zadruge, ali i članova zadruge. Međutim, moguće je da zadruge bez zaposlenih imaju loše poslovne rezultate jer je među njima veći udio zadruga u stečaju ili pred gašenjem.

Slika 2.

Struktura prihoda zadruga u 2017., u \%

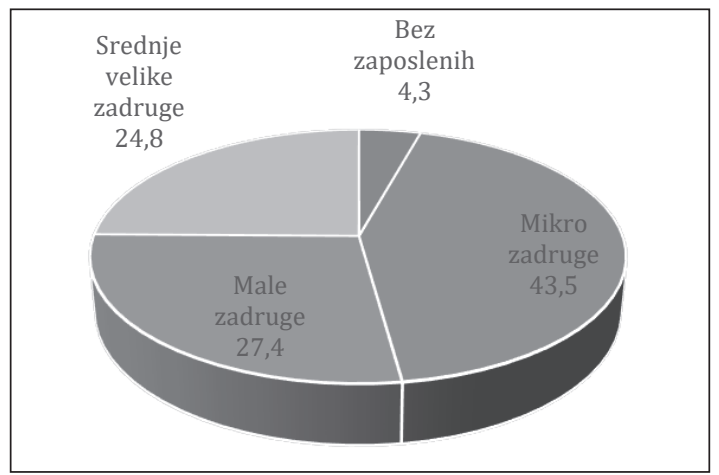

Izvor: Financijska agencija.

Slika 3.

Struktura imovine zadruga u 2017., u \%

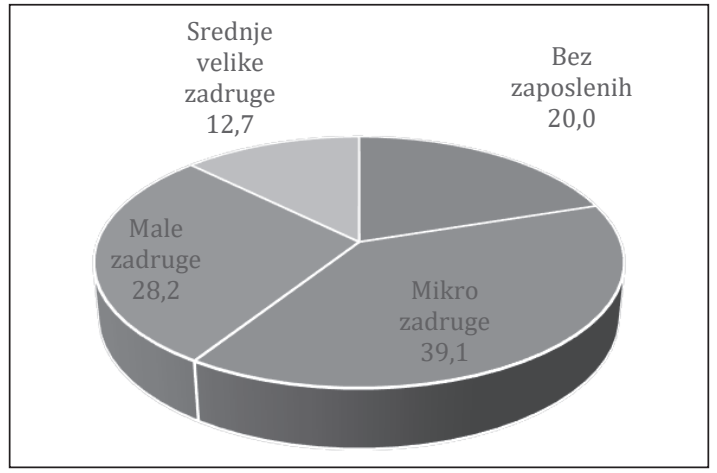

Izvor: Financijska agencija. 
Slika 4.

Struktura obveza zadruga u 2017., u \%

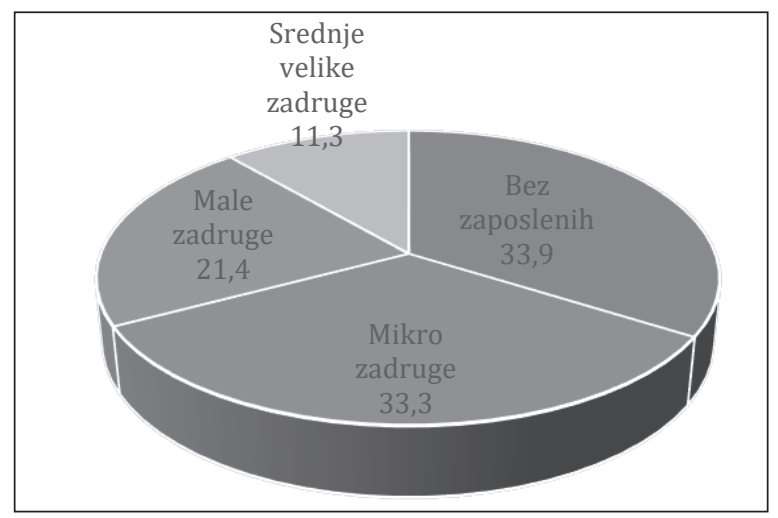

Izvor: Financijska agencija.

\subsection{Analiza zadruga prema poslovnom rezultatu}

Detaljniji uvid u financijske podatke pokazuje da se u svakom sektoru pojavljuju neke zadruge koje svojim, u pravilu lošijim, rezultatima utječu na rezultate cijelog sektora. Razlog je tome što zadruga zapravo nema mnogo, te kada se one podijele u sektore, ekstremne vrijednosti imaju veći utjecaj na vrijednosti financijskih pokazatelja. Stoga su u ovom poglavlju zadruge podijeljene na one koje su u 2017. ostvarile neto dobit i one koje su ostvarile gubitak, kako bi se vidjele razlike u njihovim financijskim pokazateljima. Od ukupno analizirane 904 zadruge njih 585 ili 64,7 posto poslovalo je s dobiti ili uz uravnotežene prihode i rashode, dok je preostalih 319 zadruga, odnosno 35,3 posto, poslovalo s gubitkom.

Razlike u rezultatima poslovanja za te su dvije skupine zadruga, očekivano, velike. Zadruge koje su ostvarile dobit ostvaruju 91,1 posto svih prihoda zadruga te imaju 5,5 puta veće prosječne prihode po zadruzi od onih koje su ostvarile gubitak (tablica 11). Povrat na kapital zadruga koje su ostvarile dobit iznosi 9,5 posto ${ }^{10}$ (tablica 12) te se po tom pokazatelju nalaze iznad najboljih europskih zadruga, kod kojih povrat na kapital iznosi 7,6 posto, odnosno nalaze se na razini američkih zadruga ${ }^{11}$. S druge strane, zadruge koje su ostvarile dobit upravljaju samo sa 72,4 posto ukupne imovine zadruga, što znači da efikasnije koriste imovinu u svrhu ostvarivanja prihoda.

10 Iako prema povratu na kapital zadruge koje su ostvarile neto dobit bolje stoje od gospodarstva u cjelini, ne možemo uspoređivati ta dva skupa poslovnih subjekata, budući da podaci za ukupno gospodarstvo sadrže i poduzeća koja su ostvarila gubitak.

$\mathbf{1 1}$ Podatak za najbolje europske i američke zadruge odnosi se na 2015. godinu. 
Tablica 11.

Odabrane stavke iz bilance i računa dobiti i gubitka zadruga prema poslovnom rezultatu u 2017., u mil. kuna

\begin{tabular}{|l|c|c|}
\hline & Zadruge s neto dobiti & Zadruge u gubicima \\
\hline Ukupni prihod & $1.497,6$ & 146,6 \\
\hline Prosječni prihod & 2,6 & 0,5 \\
\hline Ukupna neto dobit/gubitak & 69,7 & $-40,2$ \\
\hline Dobit prije oporezivanja & 78,1 & $-39,8$ \\
\hline Ukupna imovina (aktiva) & $1.667,8$ & 634,6 \\
\hline Ukupne obveze & 937,4 & 610,0 \\
\hline Prosječne obveze & 1,6 & 1,9 \\
\hline Kapital & 730,4 & 24,5 \\
\hline
\end{tabular}

Izvor: Financijska agencija.

Zadruge koje su poslovale s dobiti uspijevaju se oslanjati značajno više na kapital od zadruga u gubicima. Zadruge koje su poslovale s dobiti imaju 43,8 posto kapitala u strukturi izvora financiranja poslovanja, dok na obveze otpada 56,2 posto. Zadruge u gubicima puno su zaduženije, te u njihovoj kapitalnoj strukturi na obveze otpada 96,1 posto. Takav omjer kod zadruga u gubicima znači da im je koeficijent financiranja značajno viši $(24,9)$ nego kod zadruga koje su poslovale s dobiti $(1,3)$, odnosno da su zadruge u gubicima u prosjeku prezadužene. Slično tome i koeficijent financijske stabilnosti, koji pokazuje koliki se udio dugotrajne imovine financira iz dugoročnih izvora (kapitala i dugoročnog duga), upućuje na zaključak da zadruge u gubicima vrlo velik dio svoje dugotrajne imovine financiraju iz kratkoročnih izvora. Za razliku od toga, zadruge s dobiti u prosjeku mogu financirati svu dugotrajnu imovinu iz dugoročnih izvora financiranja.

Tablica 12.

Financijski pokazatelji zadruga prema poslovnom rezultatu u 2017.

\begin{tabular}{|c|c|c|}
\hline & Zadruge s neto dobiti & Zadruge u gubicima \\
\hline \multicolumn{3}{|l|}{ Pokazatelji profitabilnosti } \\
\hline Povrat na kapital - ROE (u \%) & 9,5 & $-163,8$ \\
\hline Povrat na imovinu - ROA (u \%) & 4,2 & $-6,3$ \\
\hline \multicolumn{3}{|l|}{ Pokazatelji likvidnosti } \\
\hline Koeficijent tekuće likvidnosti & 1,2 & 0,7 \\
\hline Koeficijent ubrzane likvidnosti (u \%) & 0,8 & 0,6 \\
\hline Koeficijent trenutne likvidnosti (u \%) & 0,2 & 0,0 \\
\hline Koeficijent financijske stabilnosti (u \%) & 106,9 & 56,3 \\
\hline
\end{tabular}




\begin{tabular}{|l|c|c|}
\hline \multicolumn{2}{|l|}{ Zadruge s neto dobiti } & Zadruge u gubicima \\
\hline Koeficijenti zaduženosti & 1,3 & 24,9 \\
\hline Koeficijent financiranja & 0,6 & 1,0 \\
\hline Koeficijent zaduženosti & 525,2 & $-1.084,2$ \\
\hline Pokriće troškova kamata (u \%) & 141,7 & 316,6 \\
\hline Pokazatelji aktivnosti & 61,4 & 169,2 \\
\hline Obrtaj zaliha (u danima) & 125,3 & 847,9 \\
\hline Naplata potraživanja (u danima) & & \\
\hline Prosječno plaćanje obveza dobavljačima (u danima) & 56,2 & 96,1 \\
\hline Kapitalna struktura i struktura imovine i obveza & 43,8 & 3,9 \\
\hline Kapitalna struktura - obveze (u \%) & 53,9 & 48,5 \\
\hline Kapitalna struktura - kapital (u \%) & 66,6 & 71,9 \\
\hline Udio dugotrajne imovine u aktivi (u \%) & 11,2 & 22,8 \\
\hline Udio kratkoročnih obveza u ukupnim obvezama (u \%) & & \\
\hline Udio zajmova u ukupnim obvezama (u \%) & & \\
\hline
\end{tabular}

Izvor: Financijska agencija.

I pokazatelji likvidnosti pokazuju da su zadruge koje su ostvarile dobit imale solidnije poslovanje. One su u prosjeku likvidnije od zadruga koje su ostvarile gubitak, odnosno imaju veću mogućnost podmirivanja kratkoročnih obveza. Ipak, treba napomenuti da zadruge općenito, a osobito one koje su ostvarile gubitak, imaju relativno velik udio kratkoročnih obveza u ukupnim obvezama. Točnije, zadruge koje su poslovale s gubitkom imaju udio kratkoročnih obveza u ukupnim obvezama u iznosu od 71,9 posto, a zadruge s neto dobiti 66,6 posto, dok prosjek cjelokupnog gospodarstva iznosi 48 posto. To znači da se čak i zadruge koje su poslovale s dobiti, i imaju bolje pokazatelje likvidnosti od zadruga koje su poslovale s gubitkom, mogu naći u likvidnosnim problemima, budući da moraju osigurati podmirenje većeg dijela obveza u kratkom roku. Na to upućuje i koeficijent ubrzane likvidnosti, koji pokazuje da zadruge u prosjeku nemaju dovoljno kratkoročne imovine (umanjene za zalihe) za pokrivanje kratkoročnih obveza. Osim toga, udio zajmova u ukupnim obvezama viši je kod zadruga nego u ostatku gospodarstva, što pokazuje veću bankovnu ovisnost zadruga. Taj omjer za zadruge s dobiti iznosi 11,2 posto, za zadruge s gubitkom 22,8 posto, dok za ostatak gospodarstva iznosi 9,1 posto.

Pokazatelji aktivnosti pokazuju da zadruge koje posluju s dobiti efikasnije upravljaju poslovanjem. Uz pretpostavku da u objema skupinama zadruga ima zadruga iz svih sektora ${ }^{12}$, podaci pokazuju da je obrtaj zaliha dvaput sporiji u zadrugama koje

12 Trajanje držanja zaliha ovisi o sektoru, pa bi taj pokazatelj trebalo uspoređivati za slične zadruge. 
posluju s gubitkom. To znači da zadruge koje imaju gubitak ne uspijevaju efikasno upravljati zalihama, odnosno da bi mogle imati zastarjele zalihe. Trajanje naplate potraživanja pokazuje da zadruge u gubicima 2,5 puta sporije uspijevaju naplatiti potraživanja od kupaca, odnosno da je novac predugo vezan u toj vrsti imovine. Stoga i ne iznenađuje što su pokazatelji likvidnosti u toj skupini zadruga nepovoljni. Poteškoće u poslovanju zadruga u gubicima najbolje pokazuje plaćanje obveza dobavljačima, koje je gotovo sedam puta dulje nego kod zadruga s ostvarenom dobiti.

Budući da među zadrugama u gubicima prevladavaju zadruge bez zaposlenih, i to s udjelom od 62,7 posto, ponovno se pokazuje da je potrebno imati zaposlenog barem jednog radnika koji bi se u potpunosti mogao posvetiti poslovanju zadruge te kako bi zadruga imala prilike razviti poslovanje i učinkovito zadovoljavati potrebe svojih članova.

\section{Zadružno poduzetništvo u Europskoj uniji i svijetu - usporedba s Hrvatskom}

Unatoč postojanju institucionalnog okvira, prethodno je poglavlje pokazalo da zadružno gospodarstvo u Hrvatskoj ima relativno malen značaj. Sličnu sliku pokazuje i usporedba s Europskom unijom. U usporedbi s prosjekom Europske unije, u Hrvatskoj je puno manji broj stanovnika uključen u rad zadruga. Dok je u Europskoj uniji u prosjeku svaki četvrti stanovnik član neke zadruge, u Hrvatskoj je u zadruge učlanjeno tek pet od 1000 stanovnika (tablica 13).

Tablica 13.

Zadružno gospodarstvo u EU i RH

\begin{tabular}{|l|c|c|}
\hline & EU* & RH * $^{*}$ \\
\hline Broj zadruga & 176.461 & 1.218 \\
\hline Broj članova zadruga & 141.502 .512 & 20.483 \\
\hline Broj zaposlenih u zadrugama & 4.707 .682 & 2.595 \\
\hline Prihod (mil. eura) & 1.004 .830 & 215,3 \\
\hline Prosječan broj članova zadruga & 802 & 17 \\
\hline Prosječan broj zaposlenih u zadrugama & 27 & 2,2 \\
\hline Prosječan prihod zadruga (mil. eura) & 5,694 & 0,177 \\
\hline Članovi zadruga na 1000 stanovnika & 277,3 & 4,9 \\
\hline Udio zaposlenih u zadrugama u ukupnom broju zaposlenih & 2,2 & 0,2 \\
\hline
\end{tabular}

Napomena: * Podaci se odnose na 2015. ** Podaci se odnose na 2016.

Izvor za EU: Cooperatives Europe (2015.). Izvor za RH: Hrvatski centar za zadružno poduzetništvo (2017.).

Ako se Hrvatska usporedi s pojedinim članicama Europske unije za koje su raspoloživi podaci o broju članova zadruga, uočava se da se Hrvatska prema broju članova zadruga na 1000 stanovnika nalazi na samom začelju među članicama Unije (slika 
5). Nizak broj članova zadruga na 1000 stanovnika prisutan je u svim posttranzicijskim zemljama, osobito u Češkoj, Rumunjskoj i Bugarskoj, dok je nešto veći broj članova zadruga u odnosu na broj stanovnika u Litvi, Slovačkoj i Mađarskoj. U prosjeku, posttranzicijske zemlje imaju 63 zadrugara na 1000 stanovnika, dok ih stare članice Unije u prosjeku imaju čak 350. Poljska je posttranzicijska zemlja s najvećom gustoćom zadrugarstva, no i kod nje je omjer članova i broja stanovnika ispod prosjeka Unije, te iznosi 210 članova na 1000 stanovnika. Prema broju članova zadruga u odnosu na broj stanovnika u Europskoj uniji prednjače Nizozemska, s većim brojem članova zadruga nego broja stanovnika, Finska i Švedska. U nekim zemljama velik dio članstva u zadrugama odnosi se na članove zadružnih banaka i osiguravajućih društava, primjerice u Nizozemskoj, Francuskoj, Njemačkoj i Austriji. Kada bi Hrvatska željela doseći gustoću zadrugarstva Portugala, odnosno zemlje s najmanjom gustoćom zadrugarstva među starim članicama Unije, omjer članova zadruga u odnosu na stanovništvo u Hrvatskoj bi se trebao uosmerostručiti.

Slika 5.

Članovi zadruga na 1000 stanovnika u zemljama Europske unije u 2015.

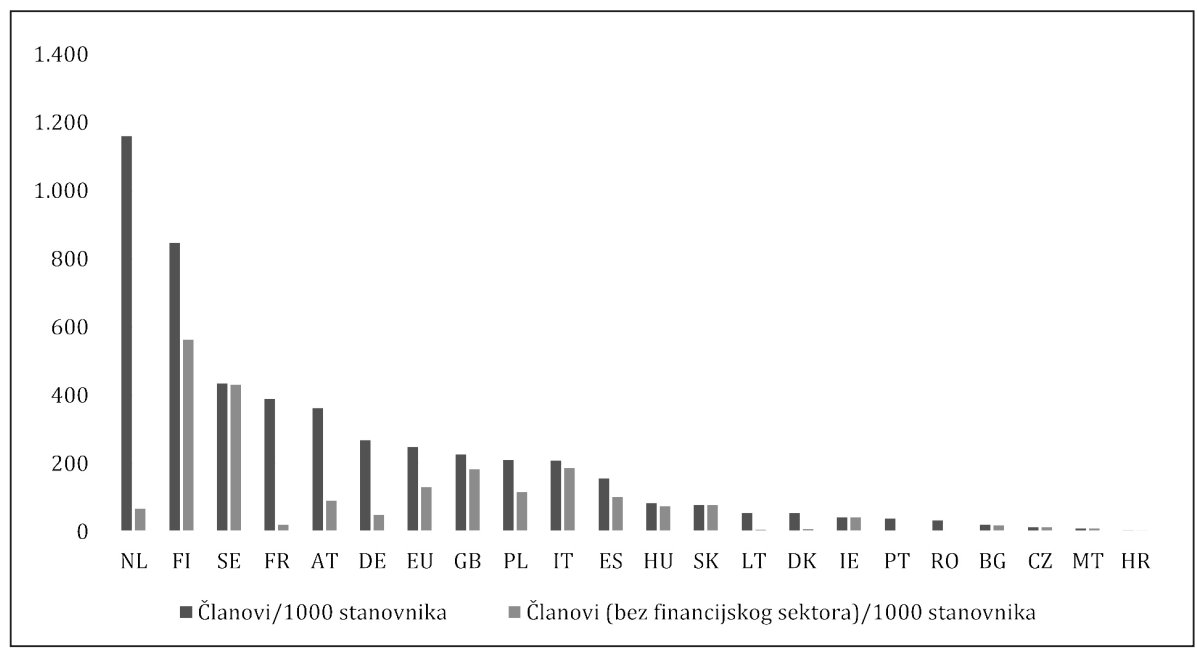

Izvor: Cooperatives Europe (2015.).

Sličnu sliku o zadružnom poduzetništvu pružaju i drugi pokazatelji. Prosječan broj članova zadruga u Hrvatskoj iznosi tek 17, dok zadruge u EU-u u prosjeku okupljaju preko 800 članova. Malen je i broj osoba koje rade u zadrugama. Radi se, u prosjeku, o tek dvije zaposlene osobe po zadruzi, za razliku od prosjeka EU-a, gdje zadruge zapošljavaju prosječno 27 osobe. Osim toga, zaposleni u zadrugama u EU-u čine 2,2 posto svih zaposlenih, dok u Hrvatskoj taj udio iznosi tek 0,2 posto. U Hrvatskoj prihod koji ostvaruju zadruge u prosjeku iznosi manje od 200 tisuća eura, dok zadruge u Europskoj uniji ostvaruju u prosjeku prihode od gotovo 5,7 milijuna eura.

Ipak, usporedba financijskih pokazatelja najboljih svjetskih zadruga i zadruga u Hrvatskoj koje su u 2017. ostvarile neto dobit pokazuje da se zadruge u Hrvatskoj 
mogu uspoređivati s uspješnim svjetskim zadrugama (tablica 14). ${ }^{13}$ Povrat na kapital i imovinu viši im je nego u prosjeku u svijetu, odnosno uspješne zadruge u Hrvatskoj usporedive su sa zadrugama iz Amerike. S druge strane, uspješne zadruge u Hrvatskoj ovise više o vlastitim izvorima kapitala za financiranje poslovanja, što bi moglo upućivati na konzervativniju poslovnu politiku zadruga, manjak poslovnih prilika koje bi iziskivale zaduživanje ili na otežan pristup vanjskom financiranju, zbog čega se domaće zadruge više oslanjaju na vlastito financiranje.

Usporedba hrvatskih zadruga koje su ostvarile neto dobit s najboljim svjetskim zadrugama pokazuje da, iako zadrugarstvo još uvijek ima relativno mali značaj za hrvatsko gospodarstvo, treba poticati osnivanje zadruga. Naime, budući da hrvatske zadruge koje ostvaruju neto dobit imaju poslovne rezultate na razini uspješnih svjetskih zadruga, može se zaključiti da dobro upravljane zadruge i u Hrvatskoj mogu ostvariti rezultate usporedive s uspješnim svjetskim zadrugama.

Tablica 14.

Financijski pokazatelji zadruga u svijetu i Hrvatskoj

\begin{tabular}{|l|c|c|c|c|}
\hline & $\begin{array}{c}\text { Kapitalna } \\
\text { struktura - } \\
\text { ukupne obveze }\end{array}$ & $\begin{array}{c}\text { Kapitalna } \\
\text { struktura - } \\
\text { kapital }\end{array}$ & $\begin{array}{c}\text { Povrat na } \\
\text { kapital }\end{array}$ & $\begin{array}{c}\text { Povrat na } \\
\text { imovinu }\end{array}$ \\
\hline Svijet* & 72,9 & 27,1 & 8,3 & 2,2 \\
\hline Amerike* & 70,8 & 29,2 & 9,5 & 2,7 \\
\hline Azija i Pacifik* & 69,4 & 30,6 & 7,5 & 2,2 \\
\hline Europa* & 75 & 25 & 7,6 & 2,0 \\
\hline Hrvatska (zadruge s neto dobiti)*** & 56,2 & 43,8 & 9,5 & 4,2 \\
\hline
\end{tabular}

Napomena: * Podaci se odnose na 2015. ** Podaci se odnose na 2017.

Izvor za svijet: International Co-operative Alliance (2017.). Izvor za RH: Financijska agencija.

\section{Diskusija i zaključak o stanju zadružnog gospodarstva}

Zahvaljujući svojim značajkama, odnosno razlikama u odnosu na organizacije koje djeluju sa svrhom ostvarivanja dobiti, kao i načelima na kojima se temelji njihov rad, zadruge imaju posebnu društvenu ulogu. Zadruge u prvi plan stavljaju potrebe svojih članova i podršku lokalnoj zajednici u kojoj djeluju. Također, zadruge su, za razliku od profitnih organizacija, spremne raditi s minimalnim prinosom ili na točki pokrića. Stoga njih mogu osnivati i voditi osobe koje inače ne bi imale pristup tržištu rada, te stjecati poduzetnička i upravljačka iskustva. Osim toga, s obzirom na to da omogućuju zadržavanje stanovništva u slabije razvijenim krajevima, da pridonose

13 Budući da samo za najbolje svjetske zadruge postoje dostupni podaci, usporedba s Hrvatskom rađena je na temelju zadruga koje su u 2017. godini ostvarile neto dobit. 
stvaranju kvalitetnih radnih mjesta i da omogućuju zapošljavanje osoba s invaliditetom i većim rizikom od socijalne isključenosti, smatra se da zadruge pozitivno utječu na ublažavanje siromaštva.

Unatoč važnoj društvenoj ulozi zadruga, analiza provedena u ovom radu pokazala je da je zadružno poduzetništvo u Hrvatskoj razvijeno daleko manje nego što bi to objektivno bilo moguće. Naime, zadruge obuhvaćaju neznatan dio hrvatskog gospodarstva te uz to u prosjeku imaju slabije poslovne pokazatelje od ostatka gospodarstva. Zadruge imaju niže prosječne prihode po zadruzi, niže povrate na kapital i imovinu, manje su likvidne te su zaduženije od ostalih poduzetnika u gospodarstvu. Iznimka su zadruge u sektoru ribarstva, koje u mnogim pokazateljima bolje stoje od drugih sektora i od ostalih poduzetnika u ribarstvu. Može se pretpostaviti da su na poslovanje tog sektora pozitivno djelovale potpore ribarskim zadrugama, pa se temeljem tog iskustva nositeljima ekonomske politike može preporučiti da zadrugama omoguće pristup mjerama državnih potpora koje su dostupne drugim poduzetnicima te da oblikuju ciljane mjere koje bi osnažile postojeće zadruge i potaknule osnivanje novih.

Naime, u Hrvatskoj postoji vrlo malo mjera javnih politika namijenjenih upravo zadrugama, odnosno te se mjere svode na mjere potpore braniteljskim zadrugama te na mogućnost dobivanja financijske potpore za početak rada proizvođačkih organizacija. To, međutim, ne znači samo da zadružni pravni oblik nije favoriziran u odnosu na druge pravne oblike. Naprotiv, on je diskriminiran budući da su zadruge isključene iz kruga korisnika mjera državnih potpora za male i srednje poduzetnike, koje se uglavnom odnose na trgovačka društva i obrte. Nadalje, osim trgovačkih društava i obrta, od zadruga su u povoljnijem položaju u smislu pristupa mjerama državne potpore i obiteljska poljoprivredna gospodarstva kao i neprofitne organizacije. Natječaji za financijske potpore obiteljskim poljoprivrednim gospodarstvima i udrugama redovno se objavljuju kako na državnoj razini, za sredstva iz državnog proračuna, tako i na lokalnoj i regionalnoj (područnoj) razini, za sredstva proračuna općina, gradova i županija.

Mjere državne potpore imale su velik utjecaj na nastanak obiteljskih poljoprivrednih gospodarstava. No, s obzirom na to da se radi o obliku gospodarenja koji nije zaseban pravni oblik, koji je stoga u velikoj mjeri izvan domašaja nadzora državnih institucija i koji je vrlo usitnjen, on ne može biti efikasan kao zadružni oblik. Istodobno, država nije svojim javnim politikama promovirala zadružni oblik gospodarenja u poljoprivredi kao onaj koji je gospodarski racionalniji jer u bitno većoj mjeri može pridonijeti iskorištavanju prednosti ekonomije obujma. Stoga danas postoji velik neiskorišteni gospodarski potencijal u području poljoprivrede, a koji se sastoji od mogućnosti udruživanja velikog broja obiteljskih poljoprivrednih gospodarstava u zadruge.

Zadruge, osim u slučaju malih zadruga, ostvaruju veći prihod po zaposlenom od ostatka gospodarstva. Iz toga se može zaključiti da zadružni način poslovanja može pružiti određene prednosti. Jedan od razloga za veću učinkovitost zadruga mogućnost je prebacivanja određenih funkcija poslovanja na zadruge, koje onda obavljaju 
te funkcije za više članova. To znači da se na zadrugu može gledati kao na svojevrsni outsourcing - poslovni subjekt koji može bolje obavljati neke poslovne funkcije za poduzetnika, a pritom poduzetnik sam ne treba dodatno zapošljavati. Na taj se način povećava učinkovitost poslovanja članova zadruge, ali i same zadruge zbog specijalizacije za određene poslove.

Iako su zadruge prisutne u svim županijama, one nisu ravnomjerno raspoređene. U nekim županijama, primjerice u Splitsko-dalmatinskoj, zadruge su prepoznate kao poželjan model poslovnog udruživanja, dok u nekim županijama posluje relativno malen broj zadruga. Neravnomjerna rasprostranjenost zadruga stoga upućuje na potrebu uspostavljanja i jačanja krovne institucije za zadružno poduzetništvo te njezine aktivnosti u promoviranju osnivanja zadruga, osobito u županijama u kojima su one danas rijetke. Budući da je analiza pokazala da postoje zadruge koje imaju vrlo dobre poslovne rezultate, čini se da bi predstavljanje uspješnih zadruga moglo pozitivno utjecati na promociju zadrugarstva. Informiranjem o primjerima dobre prakse potencijalni se osnivači i članovi zadruge iz prve ruke mogu uvjeriti u prednosti zadružnog poduzetništva.

Sve to pokazuje da kvalitetno pripremljene mjere i dobro strukturirana krovna institucija za zadružno poduzetništvo mogu pridonijeti afirmaciji tog dijela gospodarstva.

\section{Literatura}

1. Agencija za plaćanja u poljoprivredi, ribarstvu i ruralnom razvoju (2018). Godišnje izvješce o radu Agencije za plaćanja u poljoprivredi, ribarstvu i ruralnom razvo$j u$. https://www.apprrr.hr/wp-content/uploads/2018/05/Izvje\%C5\%A1\%C4\%87eo-radu-APPRRR-a-za-2017.pdf.

2. Chaddad, F. R. and Heckelei, T. (2003). Access to Capital and Firm-Level Investment Behavior in Food Industries: A Comparison of Cooperatives and Publicly Traded Firms. Annual Meetings of the American Agricultural Economics Association, July 27-30, Montreal, Canada.

3. Chesnick, D. S. (2000). Financial Management and Ratio Analysis for Cooperative enterprises. Washington: U.S. Department of Agriculture.

4. Chieh, T. S. and Weber, C. T. (2016). Editors' Foreword, in: Chieh, T. S. and Weber C. T. (Eds.). The Capital Conundrum for Co-operatives. Brussels: International Co-operative Alliance.

5. Cooperatives Europe (2015). Cooperative Europe Key Figures 2015; The Power of Cooperation. https://coopseurope.coop/resources/projects/power-cooperationcooperatives-europe-key-figures-2015.

6. Fulton, M. and Giannakas, K. (2001). Organizational Commitment in a Mixed Oligopoly: Agricultural Cooperatives and Investor-owned Firms. American Journal of Agricultural Economics, 83 (5): 1258-1265.

7. Gentzoglanis, A. (1997). Economic and Financial Performance of Cooperatives and Investor-Owned Firms: An Empirical Study, in: Nilsson, J. and van Dijk, G. (Eds.). Strategies and Structures in the Agro-Food Industries. Assen: Van Gorcum \& Comp: 171-182. 
8. Gijselinckx, C. and Bussels, M. (2014). Farmers' Cooperatives in Europe: Social and Historical Determinants of Cooperative Membership in Agriculture. Annals of Public and Cooperative Economics, 85 (4): 509-530.

9. Hanf, J. H. and Schweickert, E. (2014). Cooperatives in the Balance Between Retail and Member Interests: The Challenges of the German Cooperative Sector. Journal of Wine Research, 25 (1): 32-44.

10. Hoken, H. and Su, Q. (2018). Measuring the Effect of Agricultural Cooperatives on Household Income: Case Study of a Rice Producing Cooperative in China, Forthcoming in Agribusiness. DOI: https://doi.org/10.1002/agr.21554.

11. Hrvatski centar za zadružno poduzetništvo (2017). Godišnje izvješće o stanju zadružnog poduzetništva za 2016. godinu. http://www.zadruge.coop/upload data/site files/godisnje-izvjesce-o-stanju-zadruznog-poduzetnistva-2016.pdf.

12. International Co-operative Alliance (Međunarodni savez zadruga) (1995). Izjava o zadružnom identitetu (Statement on the Co-operative Identity), Generalna skupština Međunarodnog saveza zadruga, Manchester (23. rujna 1995).

13. International Co-operative Alliance (2017). World Co-operative Monitor - Exploring the Co-operative Economy. https://monitor.coop/sites/default/files/publication-files/wcm2017-web-1135474837.pdf.

14. International Labor Organization (Međunarodna organizacija rada) (2002). Preporuka o unapređenju zadruga (Promotion of Cooperatives Recommendation), R193 - Recommendation Concerning Promotion of Cooperatives Geneva, 90th ILC session (20 June 2002).

15. Kalogeras, N.; Pennings, J. M. E.; van der Lans, I. A.; Garcia, P.; van Dijk, G. (2009). Understanding Heterogeneous Preferences of Cooperative Members. Agribusiness, 25 (1): 90-111.

16. Kalogeras N.; Pennings, J. M. E.; Benos, T.; Doumpos, M. (2013). Which Cooperative Ownership Model Performs Better? A Financial-Decision Aid Approach. Agribusiness, 29 (1): 80-95.

17. Karami, E. and Rezaei-Moghaddam, K. (2005). Modeling Determinants of Agricultural Production Cooperatives' Performance in Iran. Agricultural Economics, 33: 305-314.

18. Lerman, Z. and Parliament, C. (1990). Comparative Performance of Cooperatives and Investor-Owned Firms in US Food Industries. Agribusiness, 6 (6): 527-540.

19. Lerman, Z. and Parliament, C. (1991). Size and Industry Effects in the Performance of Agricultural Cooperatives. Agricultural Economics, 6: 15-29.

20. Martínez-Victoria, MC.; Arcas Lario, N. and Sánchez Val, M. M. (2018). Financial Behavior of Cooperatives and Investor-owned Firms: An Empirical Analysis of the Spanish Fruit and Vegetable Sector. Agribusiness, 34 (2): 456-471.

21. Mataga, Ž. (2005). Poljoprivredno zadrugarstvo u Hrvatskoj: razvoj i temeljni problemi. Sociologija sela, 43 (1): 17-42.

22. Matijašević, A. (2005). Zadružno zakonodavstvo u Hrvatskoj: razvoj i problemi legislative poljoprivrednog zadrugarstva. Sociologija sela, 43 (1): 153-170.

23. Nedanov, A.; Franić, R. i Gugić, J. (2012). Analiza zadružnog zakonodavstva Republike Hrvatske, u: Pospišil, M. (Ur.). Zbornik radova s 47. Hrvatskog $i 7$. Mecunarodnog Simpozija Agronoma. Zagreb: Agronomski fakultet: 212-216.

24. Nilsson, J. (2001). Organisational Principles for Co-operative Firms. Scandinavian Journal of Management, 17: 329-356. 
25. Notta, O. and Vlachvei, A. (2007). Performance of Cooperatives and InvestorOwned Firms: The Case of the Greek Dairy Industry, in: Karantininis, K. and Nilsson, J. (Eds.). Vertical markets and cooperative hierarchies - The Role of Cooperatives in the Agri-Food Industry. Dordrecht: Springer: 275-285.

26. Pennerstorfer, D. and Weiss, C. R. (2012). Product Quality in the Agri-food Chain: Do Cooperatives Offer High-quality Wine? European Review of Agricultural Economics, 40 (1): 143-162.

27. Soboh, R. A. M. E.; Oude Lansink, A.; Giesen, G.; van Dijk, G. (2009). Performance Measurement of the Agricultural Marketing Cooperatives: The Gap between Theory and Practice. Review of Agricultural Economics, 31 (3): 446-469.

28. Soboh, R.; Oude Lansink, A. and Van Dijk, G. (2012). Efficiency of Cooperatives and Investor Owned Firms Revisited. Journal of Agricultural Economics, 63 (1): 142-157.

29. Svendsen, S. V. (2007). Lock-in of Farmers in Agricultural Cooperatives - Reviving the Effect of Exit by Means of Constitutional Amendments, in: Karantininis, K. and Nilsson, J. (Eds.). Vertical markets and cooperative hierarchies - The Role of Cooperatives in the Agri-Food Industry. Dordrecht: Springer: 115-136.

30. Šućur, Z.; Babić, Z. i Ogresta, J. (2017). Demografska i socioekonomska obilježja hrvatskih branitelja. Zagreb: Državni zavod za statistiku i Ministarstvo hrvatskih branitelja.

31. Tratnik, M.; Stracenski, M. i Radinović, S. (2005). Zadrugarstvo: čimbenik stabilnosti, kompetitivnosti i konkurentnosti malenih poljoprivrednih gospodarstava. Sociologija sela, 43 (1):195-213.

32. Zakon o zadrugama, Narodne novine 34 od 2011. 
Tanja Broz

Institute of Economics, Zagreb, Croatia

e-mail:tbroz@eizg.hr

Sandra ̌́valjek

Croatian National Bank, Zagreb, Croatia

e-mail:ssvaljek@hnb.hr

\title{
Microcosmos of Cooperative Economics: Where and How do the Croatian Cooperatives Operate
}

\begin{abstract}
The goal of this paper is to analyse cooperative economics in Croatia in order to determine its presence, financial performance, and indicate the problems that might be mitigated by a more active engagement with this sector. The analysis revealed that this segment of the Croatian economy is far less developed than it would objectively be possible. Cooperatives cover a very small part of the Croatian economy and have, on average, inferior financial indicators when compared to the rest of the economy. However, since cooperatives may increase the efficiency of the members' businesses, there is a large unexploited economic potential, which consists of the individual entrepreneurs' possibility to jointly constitute a cooperative.
\end{abstract}

Key words: cooperatives, cooperative economy, regional distribution, financial indicators. 